\title{
Paleozoic evolution of pre-Variscan terranes: From Gondwana to the Variscan collision
}

\author{
Gérard M. Stampfli \\ Institut de Géologie et Paléontologie, Université de Lausanne, CH-1015 Lausanne, Switzerland \\ Jürgen F. von Raumer \\ Institut de Minéralogie et Pétrographie, Université de Fribourg, CH-1700 Fribourg, Switzerland \\ Gilles D. Borel \\ Institut de Géologie et Paléontologie, Université de Lausanne, CH-1015 Lausanne, Switzerland
}

\begin{abstract}
The well-known Variscan basement areas of Europe contain relic terranes with a pre-Variscan evolution testifying to their peri-Gondwanan origin (e.g., relics of Neoproterozoic volcanic arcs, and subsequent stages of accretionary wedges, backarc rifting, and spreading). The evolution of these terranes was guided by the diachronous subduction of the proto-Tethys oceanic ridge under different segments of the Gondwana margin. This subduction triggered the emplacement of magmatic bodies and the formation of backarc rifts, some of which became major oceanic realms (Rheic, paleoTethys). Consequently, the drifting of Avalonia was followed, after the Silurian and a short Ordovician orogenic event, by the drifting of Armorica and Alpine domains, accompanied by the opening of the paleo-Tethys. The slab rollback of the Rheic ocean is viewed as the major mechanism for the drifting of the European Variscan terranes. This, in turn, generated a large slab pull force responsible for the opening of major rift zones within the passive Eurasian margin. Therefore, the first Middle Devonian Variscan orogenic event is viewed as the result of a collision between terranes detached from Gondwana (grouped as the Hun superterrane) and terranes detached from Eurasia. Subsequently, the amalgamated terranes collided with Eurasia in a second Variscan orogenic event in Visean time, accompanied by large-scale lateral escape of major parts of the accreted margin. Final collision of Gondwana with Laurussia did not take place before Late Carboniferous time and was responsible for the Alleghanian orogeny.
\end{abstract}

\section{INTRODUCTION}

Relics of the Variscan mountain chain are well known from many places in Europe (e.g., Iberia, Armorica, Moesia, the French Central Massif, the Saxo-Thuringian and Moldanubian domains, and Alpine pre-Mesozoic basement areas; Fig. 1), and modern reviews reveal their complex evolution since the Devonian (Franke, 1989, 1992; Dallmeyer and Martínez García, 1990; von Raumer and Neubauer, 1993, 1994; Keppie, 1994;
Dallmeyer et al., 1995; Matte, 1998; Arenas et al., 2000; Franke et al., 2000). As consequences of Variscan and/or Alpine orogenic events, pre-Variscan elements in these areas mostly appear as polymetamorphic domains. Geotectonic nomenclature and zonation in these classical areas of Variscan evolution mirror the main Variscan tectonic structures (e.g., Suess, 1909; Kossmat, 1927; Stille, 1951), and evidently cannot be valid for the description of pre-Variscan elements. Relics of distinct geological periods from the Proterozoic to the Ordovician have been ob- 


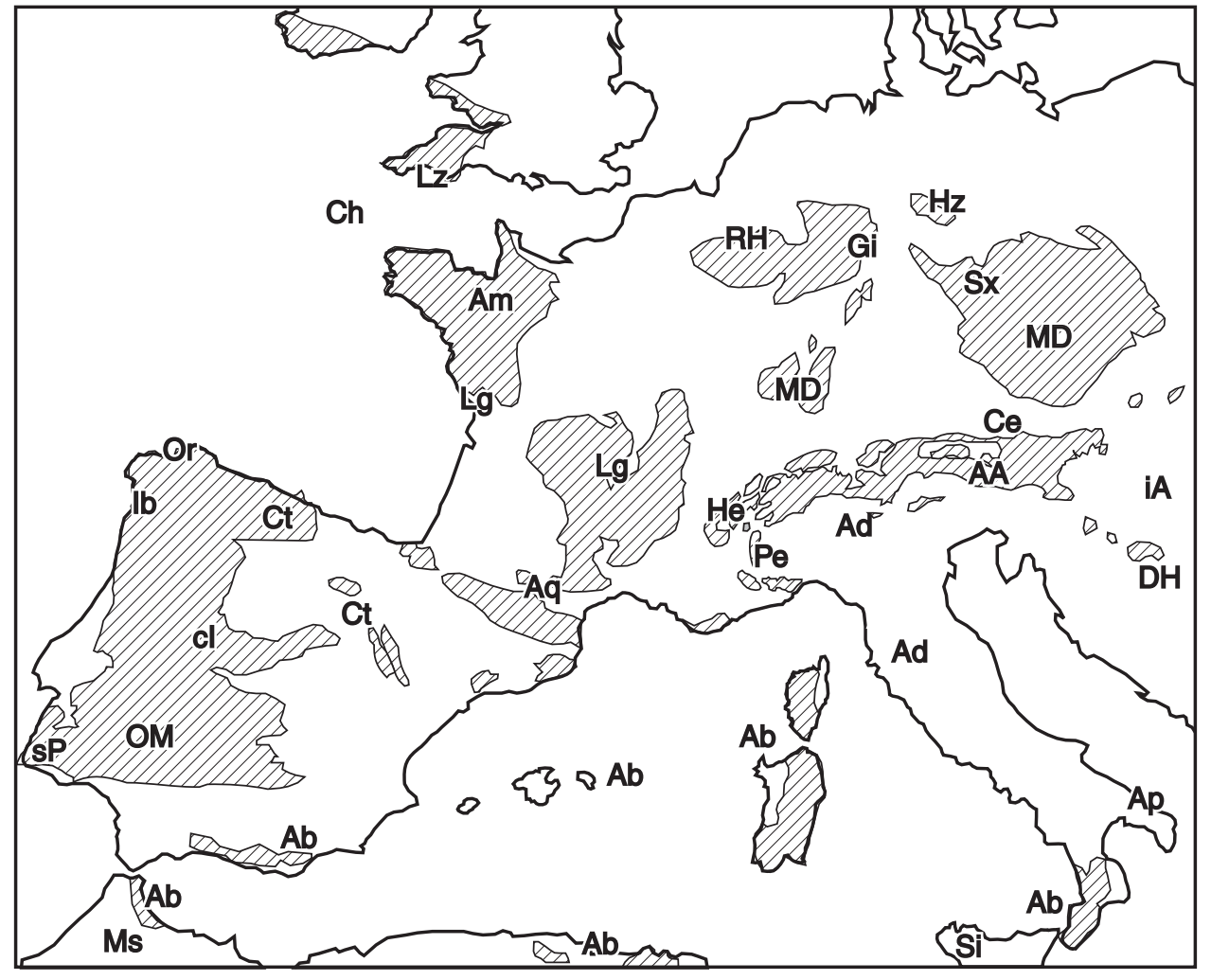

Figure 1. Present-day locations of terranes and blocks for western Europe. AA, Austroalpine; Ab, Alboran (BeticRif-Calabria-Kabbilies-Sardinia); Ad, Adria (Tuscan Paleozoic-Southern Alps); Am, Armorica; Ap, Apulia; Aq, Aquitaine (Montagne Noire-Pyrenees); Ce, Cetic; Ch, Channel; cI, Central Iberia; Ct, Cantabria-Asturia-Ebro; DH, Dinarides-Hellenides; Gi, Giesen; He, Helvetic; Hz, Harz; iA, intra-Alpine (Tizia-Transdanubian-Bükk); Ib, allochthonous units of northwestern Iberia; Lg, Ligeria (Massif Central-South Britanny); Lz, Lizzard; MD, Moldanubian; Ms, Meseta; OM, Ossa-Morena; Or, Ordenes ophiolites; Pe, Penninic; RH, Rheno-Hercynian; Si, Sicanian basin; sP, south-Portuguese; Sx, Saxo-Thuringian. served in many of the basement units. The oldest elements were considered to be part of a Late Proterozoic supercontinent (e.g., Hoffmann, 1991; Unrug, 1997) and may have been detached from what is known as Gondwana or Laurentia-Baltica or Siberia. Examples for the Gondwana origin were given by Zwart and Dornsiepen (1978) and Ziegler (1984), and tectonic complications occurring in such polyorogenic basement massifs were illustrated by Hatcher (1983) for the Appalachians. It is the aim of this contribution to discuss the plate tectonic evolution of these European regions, from the Ordovician onward, in a larger context of global palinspastic reconstructions.

\section{REVIEW OF PRE-VARISCAN EVOLUTION}

Pre-Variscan relics include, besides Cadomian-type basement units, evidence for a sequence of late Precambrian to early Paleozoic plate tectonic settings (e.g., successive stages of development of oceanic crust, volcanic arcs, active margins, and collision zones). Their corresponding evolution has to be discussed in the general framework of their peri-Gondwanan location. Alpine basement areas (Stampfli, 1996; von Raumer, 1998; von Raumer and Stampfli, 2000) as well as Avalonia have to be included in the discussion.

In von Raumer et al. (2002) we tried to compare the early Paleozoic plate tectonic evolution of Avalonia and of microcontinents formerly situated at its lateral eastern continuation along the Gondwana margin (e.g., Cadomia, and the Alpine terranes), and we proposed a similar evolution of all these terranes until the breakoff of Avalonia. Based on the presence of late Cadomian (550-520 Ma) granitoids, comparable Neoproterozoic to Cambrian detrital sediments and volcanites, and Cambrian oceanic crust, we suggested that initial stages of the Rheic ocean should have been preserved in the microcontinents formerly located in the eastern prolongation of Avalonia at the Gondwana margin (Fig. 2). Using a model of continuous Gondwana-directed subduction since the Neoproterozoic and comparing time of rifting, breakoff, and emplacement of granitoids, we distinguished several steps of a plate tectonic evolution summarized as follows.

1. A Neoproterozoic active margin setting with formation of volcanic arcs is observed along the entire length of the future microcontinents at the Gondwanan border (e.g., Fernández Suárez et al., 2000; Schaltegger et al., 1997; Zulauf et al., 1999). Granites of Neoproterozoic age (ca. $550 \mathrm{Ma}$ ), common in many Gondwana-derived basement blocks, probably indicate slab breakoff at the end of the Cadomian orogeny. Zircons in these granites carry the evidence of peri-Gondwanan origin. Latest Proterozoic to Early Cambrian sedimentary troughs developed prior to the opening of the Rheic ocean, which resulted from continued oblique subduction and rifting in a backarc situation.

2. The drift of Avalonia and the opening of the Rheic ocean were enhanced after the subduction of the mid-oceanic ridge, under Gondwana, of what we called the proto-Tethys ocean (the former peri-Gondwanan ocean, Fig. 2). Large-scale magmatic 


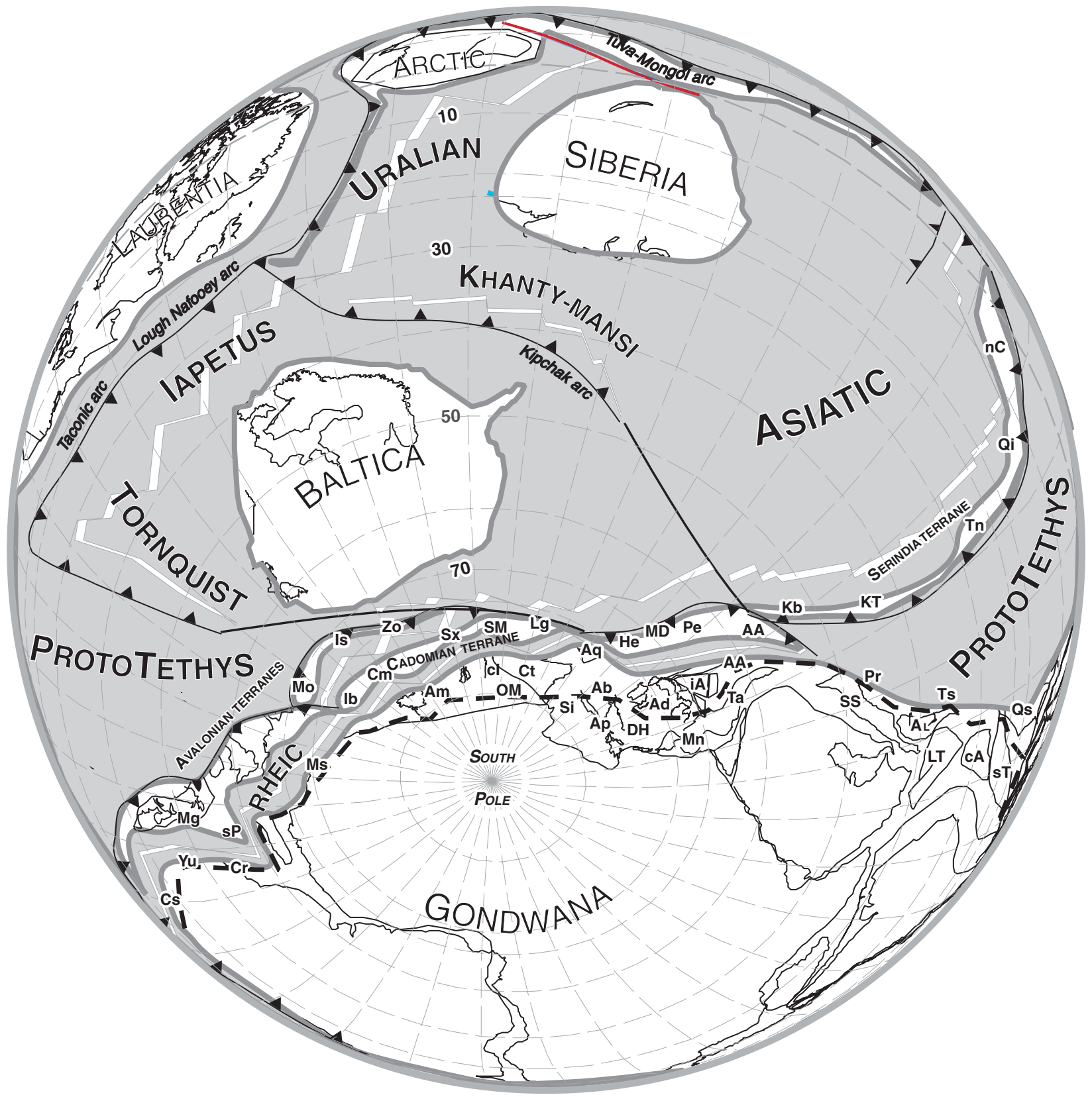

Figure 2. Location of pre-Variscan basement units at Gondwanan margin during Early Ordovician (490 Ma), modified from Stampfli (2000), showing early stages of Rheic ocean spreading. After short separation from Gondwana, Cadomia reaccreted to Gondwana in Middle Ordovician time. Thereafter Hun superterrane detached from Gondwana during opening of paleo-Tethys (dashed line along Gondwanan border). Avalonia: Is, Istanbul; Mg, Meguma; Mo, Moesia; sP, south Portuguese; Zo, Zonguldak. (Dean et al., 2000, proposed an Avalonian origin for the Istanbul Paleozoic; see also Seston et al., 2000, and Winchester, 2002). Cadomia: AA, Austro-Alpine; Cm, Cadomia; He, Helvetic; Ib, allochthons from northwestern Iberia; Lg, Ligerian; MD, Moldanubian; Pe, Penninic; SM, Serbo-Macedonian; Sx, Saxo-Thuringian. Serindia: Kb, Karaburun; KT, Karakum-Turan; nC, north China; Qi, Qilian; Tn, north Tarim. Gondwana: Ab, Alboran; Ad, Adria; Al, Alborz; Am, Armorica; Ap, Apulia; Aq, Aquitaine; cA, central Afghanistan; cI, central Iberia; Cr, Carolina; Cs, Chortis; Ct, Cantabria; DH, Dinarides-Hellenides; iA, intra-Alpine; LT, Lut-Tabas; Mn, Menderes; Ms, Meseta; OM, Ossa-Morena; Pr, Pamir; Qs, south Qinling; SS, Sanandaj-Sirjan; Si, Sicanian basin; sT, south Tibet; Ta, Taurus; Ts, south Tarim; Yu, Yucatan. 
pulses of granites and/or gabbros ca. $500 \mathrm{Ma}$ indicate this increased thermal activity (e.g., Abati et al., 1999). In the eastern continuation of Avalonia, only embryonic stages of the Rheic rifting may have existed (Fig. 2). Drifting was hampered by the still-existing mid-oceanic ridge of the proto-Tethys, the collision of which with the detaching terranes triggered the consumption of this embryonic eastern Rheic ocean. The amalgamation of volcanic arcs and continental ribbons with Gondwana occurred in a short-lived orogenic pulse. The resulting cordillera started to collapse during the Late Ordovician, leading to the opening of the paleo-Tethys rift. The chemical evolution of granitoids is the mirror of the general evolution from CambrianOrdovician rifting, to Cambrian-Ordovician active margin, and Ordovician amalgamation.

3. Mid-ocean ridge subduction during the Ordovician, in the former eastern prolongation of Avalonia, triggered not only the intrusion of many Ordovician granitoids, but also facilitated the opening of paleo-Tethys and the Late Silurian drift of the composite Hun superterrane (Stampfli, 2000). There is little evidence of this episode, neither sedimentation in a backarc setting (e.g., Saxo-Thuringian domain; Linnemann and Buschmann, 1995), nor Late Ordovician-Early Silurian active margin settings (e.g., Reischmann and Anthes, 1996) in many of the basement areas composing Cadomia (sensu lato; see following), except in the Alpine areas (Stampfli, 1996; von Raumer, 1998).

In the European pre-Variscan basement areas, hidden in the Variscan and Alpine mountain chains, a striking comparability of pre-Silurian evolutions shows that the pre-Variscan elements had similar related locations along the Gondwana margin. Many contain Cadomian basement with related evidence of Late Proterozoic detrital sedimentation and volcanic-arc development, relics of a Rheic ocean, Cambrian-Ordovician accretionary wedges, evidence of an Ordovician orogenic event with related granite intrusions, and subsequent volcanicity and sedimentation indicating the opening of paleo-Tethys. The occurrence of active margin settings during the Early Silurian supports a southward subduction of the Rheic and proto-Tethys oceans.

\section{VARISCAN COMPLICATIONS-DISCUSSION}

The pre-Variscan elements discussed herein have been interpreted from a Gondwana point of view (von Raumer et al., 2002), without regard to their post-Silurian evolution. Plate tectonic reconstructions of the Variscan history depend on paleomagnetic data and models of Variscan evolution. Independent of the model applied, the pre-Variscan elements mentioned herein were strongly transformed during the Variscan collision, and many of these relics appear today as polymetamorphic and migmatized domains, wherein much information has been lost. It is evident that size and contours of the many continental fragments have changed considerably. Nonetheless, in our reconstructions the original outlines are used to facilitate recognition of well-known basement areas. Evidently, after the Silurian, the
Gondwana-derived continental blocks (Ziegler, 1984) started to be involved in the global Variscan orogenic cycle. This is not the place to discuss all the models currently available, and the reader is referred to the references given in the introduction, and to the new observations and data presented during the field trips at the Fifteenth Basement Tectonics Meeting in A Coruña, Spain (Arenas et al., 2000; Gil Ibarguchi et al., 2000). In northwestern Spain, large-scale nappes and their ramps and horses involved all lithospheric levels, from the upper mantle to the upper crust, thus redistributing the former lateral orogenic zonation. Comparable observations come from the mid-European Variscides (Matte et al., 1990; Schulmann et al., 1991; Mingram, 1998; Stipska et al., 1998). It is evident that a pre-Variscan orogenic zonation has been involved in the Variscan collisional events (e.g., Martinez Catalán et al., 1997; Arenas et al., 2000), and relics of oceanic domains appear as fragments within large divergent orogenic belts (Pin, 1990; Matte, 1991; Martinez Catalan et al., 1999).

Although we do not discuss details about the Variscan metamorphic evolution, we add some new points of view concerning the oceanic evolution. Such a discussion is needed in relation to the different oceanic realms of the Variscan domain (e.g., Iapetus, Rheic, Galicia-Massif Central oceans) that have already been identified. Although many occurrences of so-called amphibolites known from the Variscan mountain chain still need to be geochemically characterized and dated, a comparative approach (von Raumer et al., 2002, and references therein) may furnish additional arguments for comparing plate tectonic events across continental fragments derived from Gondwana. In the following summary of related arguments, based on the inferred former peri-Gondwanan location, we assume, instead of multioceanic models, the existence of one aborted Rheic ocean, contemporaneous with the drift of Avalonia, in all basement units derived from Gondwana (i.e., Cadomia sensu lato and the Alpine terranes). This model includes the Pulo do Lobo, Galicia, and Massif Central oceans (Robardet, 2000, and also localities from the Bohemian massif; Crowley et al., 2000), and fits the interpretation of the Cambrian events in northwestern Iberia (Abati et al., 1999). Pieces of this suture zone, in the basement assemblages of Cadomia (sensu lato) and the Alpine areas, were accreted or obducted to the Gondwana margin in the Ordovician, whereas Avalonia underwent Ordovician-Silurian collision with Laurentia-Baltica. The main point we develop is that the continuation of subduction of the Rheic-proto-Tethys oceans under the remaining peri-Gondwanan blocks triggered magmatic events (the subducting ridge being a heat source) and backarc spreading (with the formation of sedimentary basins and extrusion of volcanics) from the Middle Ordovician and, finally, the opening of paleo-Tethys, from the Silurian. Therefore, this new proposal considers that the Variscan collision in Europe took place between Gondwana-derived terranes and Laurussia and not between Laurussia and Gondwana (Stampfli et al., 2000). 


\section{GENERAL PRINCIPLES}

In North America and western Europe, Variscide collisional processes are usually inferred to have ranged from the Early Devonian to the Late Carboniferous-Early Permian; and the Tethyan cycle (opening of the Alpine Tethys-Central Atlantic system) not to have started before Middle Triassic time. An apparent lack of major tectonic events during the Permian and Triassic is certainly responsible for the focus of attention on the Carboniferous history of the Variscides of Central Europe. However, the Variscan domain extends over the entire Alpine area and even further in the Dinarides and Hellenides. It also extends in time as deformations become younger, possibly grading into the eoCimmerian (Middle to Late Triassic) deformations, southward and eastward. This assumption is based on the fact that the paleo-Tethyan domain was not fully closed in southeastern Europe before the Late Permian. This is shown by Early Permian to Middle Triassic fully pelagic sequences found in Sicily (Catalano et al., 1988) and similar Carboniferous to Middle Triassic sequences in Crete (Krahl et al., 1986; Stampfli et al., 2002), located at the southern border of the Variscan domain. In the Hellenides and farther east, the final closure of this oceanic realm generally took place during the Carnian (Şengör, 1984).

Stampfli et al. (1991) and Stampfli (1996) discussed this diachronous closure of the large paleo-Tethys ocean, insisting on the development of backarc oceans or basins within the Permian-Triassic Eurasian margin (Ziegler and Stampfli, 2001) and the closure of paleo-Tethys between terranes drifting away from Eurasia (e.g., Pelagonia; Vavassis et al., 2000) and terranes drifting away from Gondwana (the Cimmerian blocks of Şengör, 1979; Stampfli, 2000; Stampfli et al., 2001a, 2001b).

Subsequently, the Atlantic-Alpine-Tethys system opened north of this eo-Cimmerian collisional zone, which thereafter was fully incorporated into the Alpine fold belt. This explains why the end member of the Variscide orogeny, the eo-Cimmerian event, is usually not taken into consideration by many. For most of those who study the Hercynian, the southern part of Variscan Europe (e.g., Spain, southern France) is usually regarded as stable Gondwana, which certainly it was in early $\mathrm{Pa}-$ leozoic time, whereas it was part of Gondwana-derived terranes accreted to Laurussia between the Late Devonian and Early Carboniferous. We formerly grouped these terranes as the Hun superterrane (von Raumer et al., 1998; Stampfli, 2000). In view of their relatively independent kinematic evolution (Fig. 3), we propose labeling its eastern components (Karakum-Turan, Tarim, north China, south China, north Tibet, and Indochina) the Asiatic Hunic terranes, whereas its western part is labeled the European Hunic terranes and comprises three major blocks: Armorica (sensu lato), Cantabria-Aquitaine-Ligeria-Moldanubia, and Alboran-Adria-intra-Alpine-Cetic (Fig. 4).

The main outcome of this proposal is that the Variscan collision must be polyphase and polymetamorphic. Initially it was made of the accretion of major terranes along the European seg- ment of the passive margin of Laurussia (Avalonia), corresponding to the closure of the Rheic ocean in the Late Ordovician (Fig. 3). Thereafter, Gondwana collided with Laurussia, including previously accreted terranes, mainly along the Alleghanian segment of Laurussia; this last event was diachronous and younging eastward and corresponded to the closure of the paleo-Tethys.

This scheme implies that after the accretion of the European Hunic terranes to Laurussia (Avalonia), the ocean located to the south of them (paleo-Tethys) started subducting northward, the Laurussian margin becoming an active margin. Subsequent subduction of the mid-oceanic ridge of paleo-Tethys led, in Visean time, to a Variscan cordillera stage.

\section{HUN SUPERTERRANE}

The European Hunic terranes include all continental fragments accreted to Laurussia during the Variscan cycle and inferred to have previously been in lateral continuity with Avalonia along the Gondwana margin (Fig. 2). We place Armorica (sensu lato) (Ossa-Morena, Central Iberia, Brittany, SaxoThuringia) north of North Africa (Fig. 2) based on paleomagnetic data (e.g., Torsvik and Eide, 1998; Torsvik et al., 1992) and sedimentological and faunal data (e.g., Paris and Robardet, 1990; Robardet et al., 1994; Robardet, 1996). These data do not show a major separation of Armorica from Gondwana before the Early Devonian. We propose that all the other Hunic terranes were in lateral continuity to Armorica (sensu lato), forming a ribbon-like superterrane. Their drifting from Gondwana is delimited by paleomagnetic data from the eastern part of the European Hunic terrane, like the Noric-Bosnian block (Schätz et al., 1997) and the Bohemian block (Krs and Pruner, 1999).

The Asiatic Hunic terranes elements are represented by Turan and Pamir (the Kara-Kum-Tarim terrane of Khain, 1994; Zonenshain et al., 1990), together with Tarim and north China, which are inferred to have escaped from Gondwana in the Early Devonian. This escape followed the accretion to the northern parts of these regions of the Serindia terrane in the Late Silurian-Early Devonian (Meng and Zhang, 1999; Yin and Nie, 1996), as well as the accretion of island arcs in Vietnam (Findley, 1998) and east China (Hutchison, 1989) at the same time; a similar development is also found along the Australian margin (e.g., Foster and Gray, 2000).

Therefore, the Hun superterrane in Early Ordovician (Fig. 2) to Early Silurian reconstructions is spread over a relatively large paleolatitudinal area (from $60^{\circ}$ south to the equator). Changes of facies can be expected between Armorica and terranes in the Alps (e.g., Carnic, Austroalpine, and intra-Alpine domains) located within the tropical zone, which present a Silurian to Carboniferous stratigraphic evolution very similar to that of the Gondwanan margin in Iran (Alborz) and Turkey (Taurus).

The prerift-synrift sequences of the Hun superterrane present a uniform sedimentary evolution equal to that found on the Gondwanan border. For example, in the Armorica (sensu lato) 


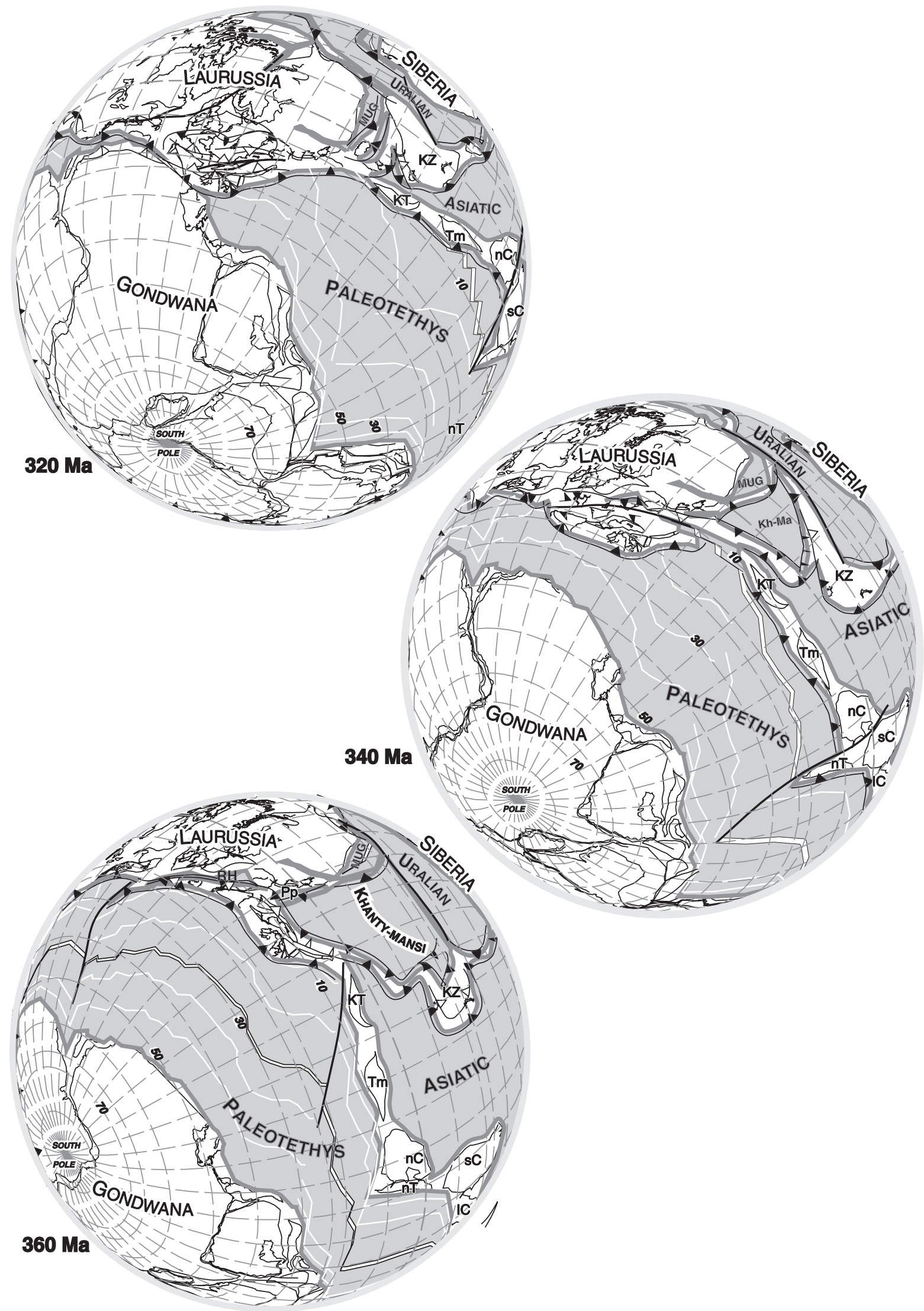




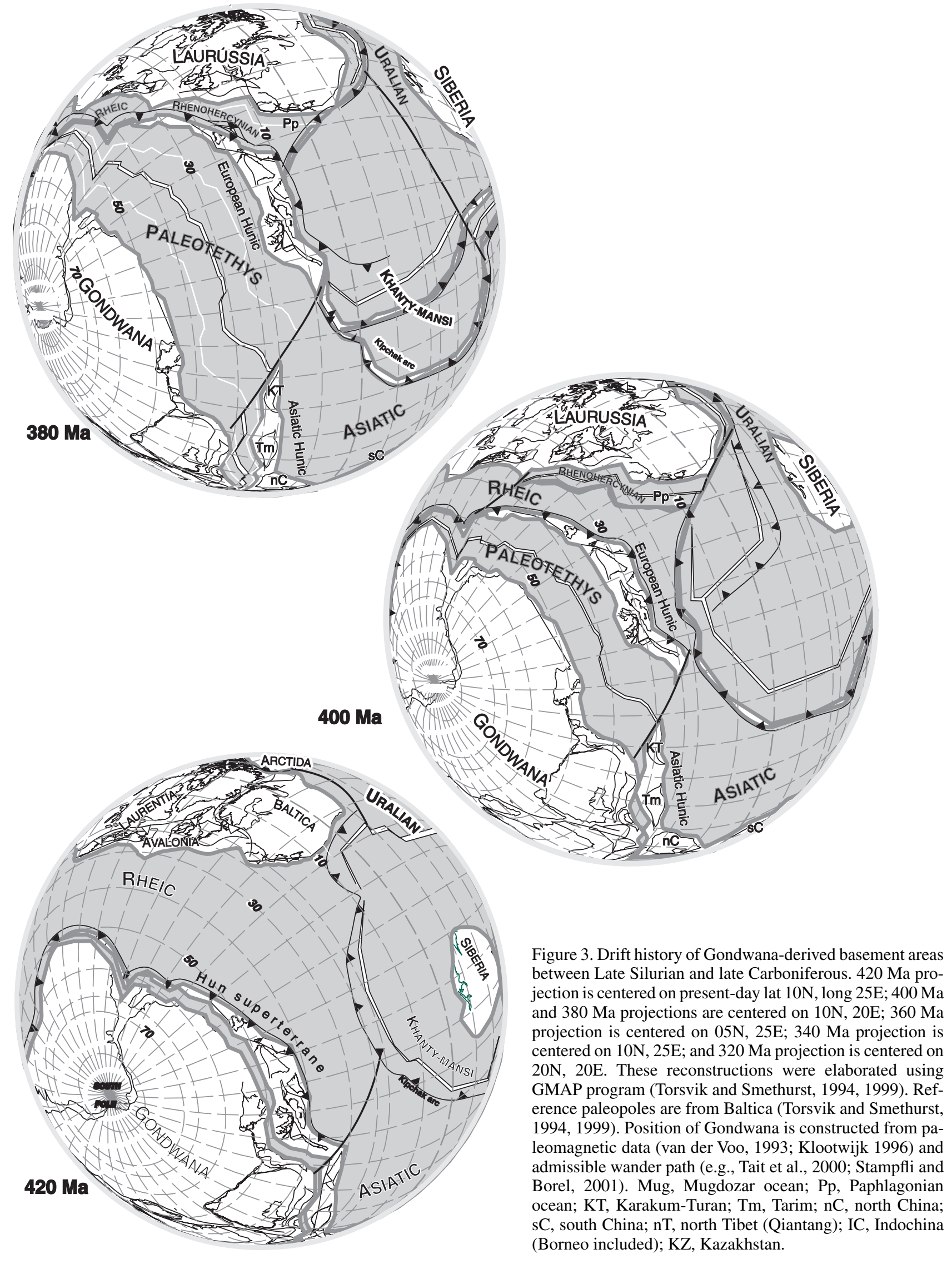




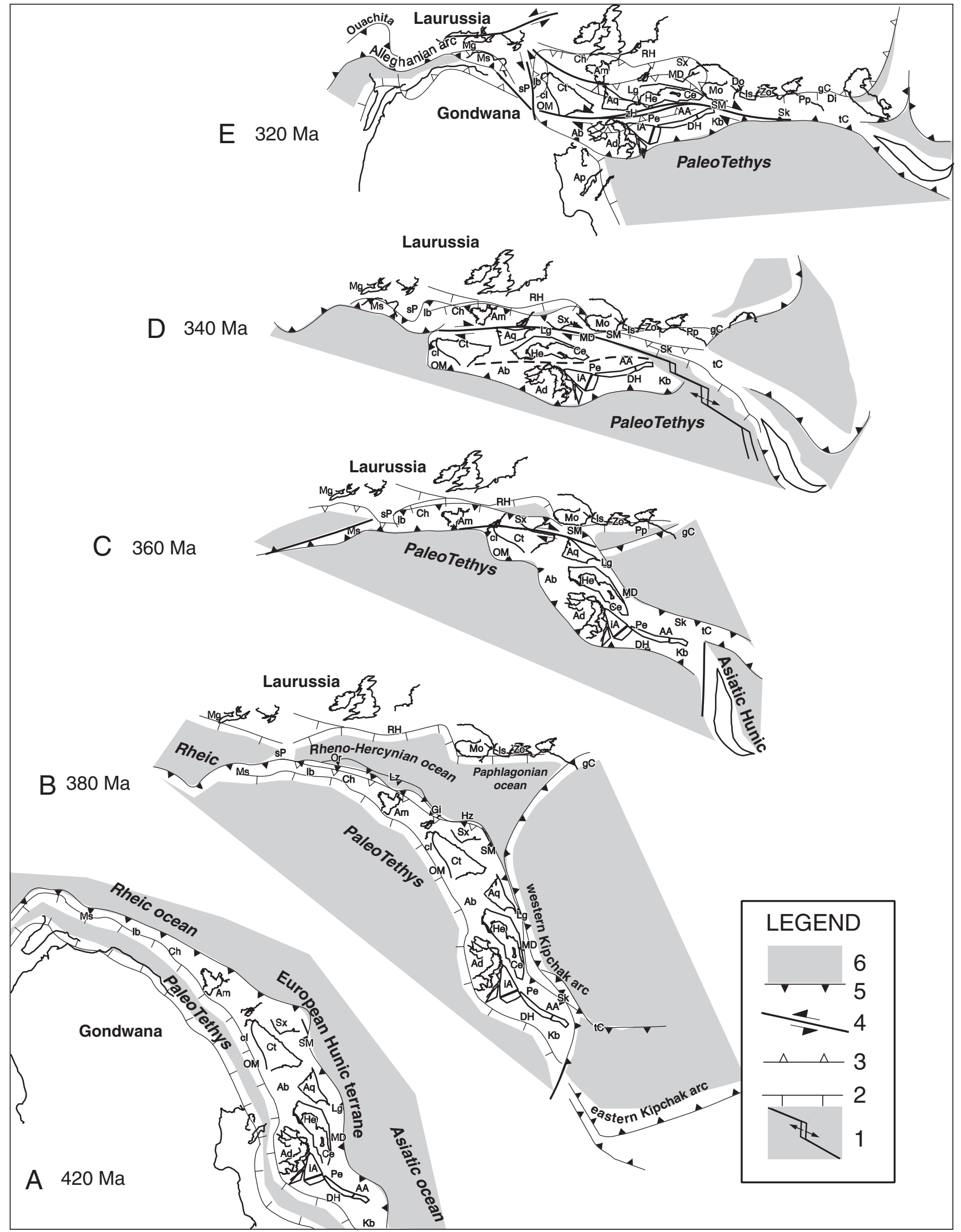


segment (Robardet et al., 1994), Late Ordovician clastics (including minor volcanics) representing synrift formations are capped by Ashgillian glacial marine deposits, related to an ice cap that possibly developed on the nascent rift shoulders (e.g., Sardinia, Ghienne et al., 2000; Taurus, Monod et al., 2002). Early Silurian marine sediments containing cherts represent a southward deepening toward the rift zone and are dominated by black graptolite shales. These anoxic Silurian deposits characterize the widening of the rift zone, but also show that connections with major oceans were not yet realized. Silurian flood basalts have been reported in many areas, and can be regarded as contemporaneous with the onset of seafloor spreading.

The postrift evolution of the European Hunic terranes differed greatly depending on their final position in relation to the Rheic suture to the north or the paleo-Tethys suture to the south. The present juxtaposition of terranes cannot be used readily to understand their transformation during the Devonian and Carboniferous. Some terranes were deeply metamorphosed during the Middle Devonian, others were affected later in Visean time (340 Ma), and flysch development on some blocks did not start before the late Carboniferous (310 Ma). Thus it is obvious that some blocks were not involved in the first phase of metamorphism, which must have affected mainly the leading edge of the superterrane, being related to the subduction and suturing of the Rheic ocean. The European Hunic terranes were finally accreted individually to Laurussia, but not before the Visean, and were accompanied by widespread metamorphism and development of flysch. The former could be due to imbrication of the terranes and crustal thickening processes, or also to the subduction of a remnant mid-ocean ridge in the paleo-Tethys ocean (Fig. 3).

Large parts of the Hun superterrane kept Gondwanan faunal characteristics at least until Early Devonian time. The conclusion that a large ocean never separated Armorica and Gondwana (Robardet et al., 1990) could be explained by a connection between Gondwana and the Hun superterrane throughout its drifting history, being, in its westernmost sector, always attached to South America (Fig. 3). However, these Gondwanan faunal characteristics disappeared in Praguian time, when similar spore assemblages are found in North Africa and in the Rheno-Hercynian domain (Paris and Robardet, 1990). This can be explained if the Hun superterrane is viewed as a land bridge

Figure 4. Detailed plate tectonic evolution of pre-Variscan units preserved in European Variscan mountain chain (see text for explanation). AA, Austro-Alpine; Ab, Alboran; Ad, Adria-south Alpine; Al, Alborz; Am, Armorica; Ap, Apulia; Aq, Aquitaine; Ce, Cetic; Ch, Channel; cI, central Iberia; Ct, Cantabria; DH, Dinarides-Hellenides; Di, Dizi; Do, Dobrogea; gC, great Caucasus; Gi, Giessen; He, Helvetic; Hz, Harz; $\mathrm{iA}$, intra-Alpine; Ib, northwestern Iberia allochthon; Is, Istanbul; Kb, Karaburun; KT, Karakum-Turan; Lg, Ligerian; Lz, lizard; MD, Moldadubian; Mg, Meguma; Mo, Moesia; Ms, Meseta; OM, OssaMorena; Or, Ordenes ophiolites; Pe, Penninic; Pp, Paphlagonian; RH, Rheno-Hercynian; Sk, Sakarya; SM, Serbo-Macedonian; sP, south Portuguese; Sx, Saxo-Thuringian; tC, trans-Caucasus; Zo, Zonguldak. between the two domains. This also supports the idea that the collision of Armorica (sensu lato) with the Eurasian domain (or Eurasian outliers) occurred ca. $380 \mathrm{Ma}$. An earlier collision (Silurian) is not supported by these faunal data, or by the lack of Silurian synorogenic deposits on the Eurasian (Avalonian) margin (e.g., the Rheno-Hercynian domain) facing the Rheic ocean.

There seems to be a contradiction between the inference that Armorica should have docked with Laurussia in Middle Devonian time and the final welding in Namurian time, after the closure of the Rheno-Hercynian domain. To reconcile these different lines of evidence, we propose that Armorica collided in Middle Devonian time with blocks detached from the Laurussian (Avalonian) margin during an Early Devonian rifting event. The latter led to the opening of the Rheno-Hercynian basin in the Emsian, within the southern passive margin of Laurussia. The oceanic nature of this basin (the Rheno-Hercynian ocean) is proven by the ophiolitic and pelagic remnants found in the Lizard, Giessen, and Harz nappes.

There are other problems associated with the present juxtaposition of the different terranes. The Cantabrian-Aquitaine terrane (Fig. 4) developed a flysch sequence only in Moscovian time (ca. $310 \mathrm{Ma}$ ) and was finally juxtaposed with high-grade metamorphic nappes of the Galician zone, where the metamorphism is much older (Middle Devonian). The LigerianMoldanubian cordillera, extending from southern Brittany to central Europe, is also juxtaposed to areas to the north (Armorica sensu lato) and to the south (Aquitaine terrane, comprising the Montagne Noire and Pyrenees), where flysch development only started at the earliest in the late Visean or Namurian. However, large parts of the cordillera were strongly metamorphosed before that time. Relics of a major Middle Devonian metamorphic event are found in nearly all the metamorphic domains of the Variscan orogen. This has been conventionally interpreted as a collision involving major continents (i.e., Gondwana and Laurussia), but no syncollisional flysch has ever been described in neighboring regions and Gondwana was never close enough to Laurussia to generate a continent-continent collision (Tait et al., 2000; Stampfli and Borel, 2002).

Our model (Figs. 2 and 4A) places all the European Hunic terrane segments in continuity with each other in order to avoid these contradictions. The leading, northern border of the superterrane is regarded as an active margin, affected by metamorphism and plutonism, whereas its hinterland stayed away from this tectonothermal activity and developed a passive margin sedimentary succession. This situation prevailed until the Late Devonian (Fig. 4C), when major transcurrent events displaced the eastern segments westward and intraterrane collisions took place. The latter were accompanied by widespread flysch development and the building of a Visean cordillera, usually with diverging boundaries around the major blocks, giving rise to double-vergent cordilleras (e.g., Matte, 1991; Neubauer and Handler, 2000). The Rheic suture would have been located along the northern active margin of the superterrane, whereas the paleo-Tethys suture should be located along the southern border of 
the superterrane. However, in view of the major Carboniferous lateral displacements and rotation (Edel, 2000, 2001), suture duplication took place and led to present-day multiocean models.

The present southernmost portion of the European Hunic terrane (the Noric-Bosnian terrane of Frisch and Neubauer, 1989), comprising Alboran, Adria, the intra-Alpine domain (Carnic and Julian Alps, Tizia, Apuseni, Transdanubian, and Bükk units), and domains located in the Dinarides and Hellenides, together with north Sardinia and part of the southern Alps, was transported southwestward during the final LaurussiaGondwana collision in the late Carboniferous (Fig. 4E). It collided with the Visean cordillera to form a double vergent orogen (Neubauer and Handler, 2000), following the fast northward drift of Gondwana (Fig. 3). Other metamorphic units found in the Alps (e.g., Cetic terrane) represent part of the Visean cordillera, possibly transported westward with the Noric-Bosnian block. In this context the Penninic domain would have been located formerly to the east of the Helvetic domain (Giorgis et al., 1999). This late Carboniferous collisional event was responsible for the final tectonic configuration of the Variscan orogen. These southernmost Variscan units are also characterised by the development of late Carboniferous magmatic arcs along their southern margins, dominated by calc-alkaline intrusions (Stampfli, 1996, and references therein), extending from the Alboran domain (e.g., Calabria with a transition from arc to rift between 295 and $275 \mathrm{Ma}$; Acquafreda et al., 1994) to the Hellenides (Vavassis et al., 2000) and possibly to the Pontides. The magmatic arcs were replaced in Permian time by major rift zones leading to the opening of backarc basins in Late Permian-Triassic time (Stampfli, 2000; Stampfli et al., 2001a, 2001b; Ziegler and Stampfli, 2001).

The Carboniferous lateral displacements and rotations imply the presence of major transcurrent faults and the opening of Gulf of California-type oceans within the European Hunic terrane (Fig. 4D). It is obvious that high-pressure rocks characterizing the Middle Devonian event had to reach the surface relatively rapidly, and the transcurrent movements were locally largely transtensive, creating intramountain basins, usually starting in the Late Devonian and found in the middle of the Ligerian-Moldanubian cordillera. Younger Carboniferous coal basins are also widespread. In this context the Zone Houillère (Cortesogno et al., 1993), extending over $100 \mathrm{~km}$ or more in the Penninic domain (Fig. 4E), is regarded as a late Carboniferous pull-apart basin along one of these major faults (Giorgis et al., 1999). It was accompanied by late Carboniferous-Early Permian granites and minor gabbros, also found elsewhere in the Alps (e.g., Capuzzo and Bussy, 2000) and emplaced in a scenario of cordillera construction and destruction, but in a general context of a still active margin.

Pelagic sequences of the Chios-Karaburun domain in the Aegean region (Stampfli et al., 2002), juxtaposed with Variscan metamorphic blocks (Pelagonia, Sakarya), could also be part of such gulf-like deep basin and/or of the paleo-Tethys accretionary prism (Kozur, 1997, 1998). Carboniferous to Permian mid-ocean ridge basalt (MORB) found in the Tavas unit of the Lycian nappe (Kozur, 1999; Kozur et al., 1998), and in eastern Iran (Ruttner, 1993) could be related to such Gulf of California-type oceans and/or to the paleo-Tethys (Fig. 4D).

These Visean lateral displacements would also involve major crustal thickening in transpressive areas and the buildup of high reliefs, leading to a cordillera stage, which lasted as long as a relatively buoyant part of the paleo-Tethyan slab was subducting under the Eurasian margin. The major geodynamic event at that time was the subduction of the paleo-Tethys midocean ridge. Thereafter, from the Late Carboniferous onward, the increasing age of the subducting paleo-Tethyan slab generated important slab rollback and general extension affected the cordillera from the Early Permian.

\section{MIDDLE DEVONIAN PHASE}

The opening of the paleo-Tethys along the European Hunic segment and westward is viewed as backarc spreading related to Gondwana-directed (southward) subduction of the Rheic ocean (Fig. 3). The principle governing the drifting of the European Hunic terranes away from Gondwana is the roll-back toward Laurussia of the Rheic slab after Ordovician subduction of its mid-oceanic ridge. The strong pull force of the major subducting Rheic slab also triggered the opening of rifts in the subducting plate, leading to the opening of small oceanic basins (the Rheno-Hercynian ocean). This could explain the early collision (during the Devonian) of Gondwana-derived European Hunic terranes with Laurussia-derived terranes, whereas major collision and closure of the Rheno-Hercynian basin only took place in Late Carboniferous time. We review next the evolution of the intervening elements, the Rheno-Hercynian basin, the European Hunic active margin in Armorica, the Ligerian cordillera, the composite Middle Devonian event, and the Appalachians.

\section{Rheno-Hercynian basin}

The Rheno-Hercynian basin is characterized by important volcanism from the Early Devonian (e.g., Walliser, 1981; Ziegler, 1988) that extended through most of the Devonian Period. Geochemical characterization of this volcanism (Floyd, 1995) has shown the purely ensialic extensional nature of this basin, and the absence of any subduction-related signatures. MORBs have been found in many places (Lizard, Giessen, Harz) and point to seafloor spreading, most likely starting in the Emsian. From the Namurian onward, this basin became a flexural basin in the foreland of the advancing Variscan nappes; the sedimentary records do not show evidence of any tectonic event before this.

The prerift sequence is locally composed of relatively complete Ordovician to Silurian sequences (e.g., east of the Rhine; Franke, 1995), or a Silurian sequence with a gap between the Silurian and Devonian (e.g., Moravo-Silesian region; Dvorak, 1995). Therefore, there is no indication of any middle Paleozoic 
(Caledonian) event in what we regard as the hinterland part, i.e., the southern passive margin of the Avalonia terranes, whereas by contrast, in its front part (e.g., the present northern Variscan foreland), the Ordovician-Silurian sequence is clearly deformed due to the suturing of Avalonia to Baltica. The rift shoulder uplift occurred in the Early Devonian, marked by clastic input derived from the south or by a so-called Caledonian unconformity in the Rhenish Massif. Thereafter, sedimentation graded from Early Devonian synrift deposits to Middle Devonian to early Carboniferous pelagic deposits (Franke, 1995).

\section{European Hunic active margin in Armorica (sensu lato)}

The accretionary prism to the south of the Rheno-Hercynian ocean is composed of the Giessen-Harz nappes and the northern Phyllite zone. The mid-German Crystalline High played the role of backstop; it is characterized by volcanic-arc activity in Silurian time (e.g., Reischmann and Anthes, 1996; Anthes and Reischmann, 2001). Pelagic sediments, extending from the Silurian to the Early Carboniferous, are found in melange or slivers in the accretionary sequences together with MORB and other basalts of intraplate affinity (seamounts; e.g., Flick et al., 1988; Nesbor et al., 1993). The Lizard ophiolite of Cornwall is considered to be a Devonian ophiolite; its emplacement in the accretionary prism was dated as Famennian (365-370 Ma) by Sandeman et al. (1995) and could correspond to the collision of the Rheno-Hercynian mid-oceanic ridge with the prism.

The Rheno-Hercynian prism evolved from an older accretionary belt developed during the southward subduction of the Rheic ocean in Silurian time. The Rheic prism incorporated a detached Eurasian block, located south of the Rheno-Hercynian ocean; detached from the already thinned Avalonian passive margin, this block could have been easily subducted. Its underplating and the subduction of the buoyant young Rheno-Hercynian oceanic lithosphere provided the necessary condition for Devonian high-pressure rocks to be exhumed. The absence of pelagic material older than Emsian in the Giessen-Harz nappe makes it difficult to place the Rheic prism in this domain; therefore, the Rheic suture should be placed in the Northern Phyllite zone (Franke, 2000). In the Wippra area of the Phyllite zone, MORBs are supposed to be partly of Ordovician and Silurian age (Meisl, 1995), thus representing the Rheic ocean floor. Ordovician and Silurian fauna are described in this zone, some with tropical or even boreal affinities, which can be taken as a Rheic signature.

A Silurian high-pressure event, recorded in the Leon domain in northern Brittany (Le Corre et al., 1991), could be regarded as a western continuation of this Rheic suture. In Galicia (Marcos et al., 2000; Arenas et al., 2000) high-pressure metamorphism in the allochthonous nappe is in the range 390-380 Ma. This Middle Devonian metamorphic complex comprises several types of Ordovician ophiolitic fragments transformed into eclogites, protolith ages ranging from 490 to
$460 \mathrm{Ma}$ and therefore possibly pertaining to the Rheic ocean. It also contains other ultramafic rocks (e.g., in the middle of the Ordenes complex) with younger ages (390-380 Ma) (Ordoñez Casado, 1998; Díaz García et al., 1999; Pin et al., 2000), most likely representing the extension of the Rheno-Hercynian ocean in that region (Fig. 4B). Thus the Middle Devonian event would have sutured the Rheic ocean and created a new accretionary wedge, including ophiolites of the Rheno-Hercynian ocean. The second metamorphic event in the Cabo Ortegal sequence, dated as ca. 345-350 Ma (Ordoñez Casado, 1998), would correspond to the subduction of the paleo-Tethyan mid-oceanic ridge and the buildup of the Visean cordillera. Younger ages (330-345 Ma) were found in more external domains in the Ossa-Morena zone (Ordoñez Casado, 1998) and mark the final suturing of Armorica (sensu lato) with the South Portuguese promontory. The Beja-Acebuches ophiolitic complex, separating the OssaMorena zone from the South Portuguese zone (Oliveira and Quesada, 1998; Eguiluz et al., 2000), would then correspond again to the Rheic suture. The Pulo do Lobo accretionary complex, located in a more external position, comprises normalMORB remnants, unconformably overlain by Late Devonian flysch. Therefore, it can be regarded as the Rheic accretionary prism, comprising a fragment of the Rheno-Hercynian ocean.

The Late Devonian-Carboniferous development of the South Portuguese zone would be directly related to the onset of paleo-Tethys northward subduction, after the Middle Devonian event. The flysch of the South Portuguese zone was derived from backarc type basic rocks that cannot be of Rheno-Hercynian origin, but could be paleo-Tethyan. Thereafter, there is a widespread development of a volcanic-sedimentary complex (the Pyrite Belt) of Late Famennian-Visean age and bimodal signature, where felsic volcanics predominate (Thiéblemont et al., 1994). This belt may represent a forearc-type basin to the newly established active margin of Laurussia. Such Late Devonian basins, where extension predominates, are also known in the Meseta and Meguma-Avalon domain (e.g., Piqué and Skehan, 1992). These basins characterize the subduction and rollback of the nonbuoyant northern part of the paleo-Tethyan slab. As subduction proceeded, the mid-ocean ridge finally collided with the margin, probably in Visean time, generating numerous granitic intrusions and closing these basins. Oroclinal bending of the cordillera then took place and deformed the originally linear features of the active margin (Weill et al., 2001). Such an oroclinal bending of a large terrane was recently proposed by Johnston (2001) for the Great Alaskan Terrane (SAYBIA).

\section{Ligerian cordillera}

In our model, suturing of the Rheic ocean took place all along the outer border of the western part of the European Hunic terranes during a Middle Devonian accretionary phase (Fig. 4B). We have already extended the situation described herein from $\mathrm{Ar}$ morica (sensu lato) to the Iberian allochthonous units of Galicia, and we infer that it extended eastward to the Münchberg nappe 
and to the western Sudetes. However, this Middle Devonian event also affected areas located south of the Armorica (sensu lato) domain. The Middle Devonian eo-Variscan metamorphic event affected the Massif Central and other northern European Variscan units (Faure et al., 1997) and was accompanied by Givetian-Frasnian high-pressure events dated as 380-370 Ma. This event, affecting simultaneously areas now imbricated in the entire Variscan orogen, could not be a major continent-continent collision, because Gondwana was still far away to the south at that time (e.g., Tait et al., 2000; Stampfli and Borel, 2002), and the Rheno-Hercynian ocean far from closing (Fig. 3). To avoid multiplying the number of oceans and terranes, we infer that all the areas affected by this Ligerian phase were formerly located on the leading edge of the eastern part of the European Hunic terranes. An example of this is the Middle Devonian suture between the Saxo-Thuringian and Tepla-Barrandian domains (Franke et al., 1995), where the Saxo-Thuringian domain, being of clear European Hunic affinity, cannot represent a block detached from Laurussia during the opening of the Rheno-Hercynian ocean. However, the sedimentary sequences in the Saxo-Thuringian basin did not record the Middle Devonian collisional event; pelagic conditions predominate from Silurian to Early Carboniferous time (Falk et al., 1995). Therefore, as is the case for many other parts of this Middle Devonian Rheic suture, it must have been laterally displaced, and the present relationship between the two domains remains ambiguous.

The same reasoning could be applied to other potential Rheic suture zones like the Moldanubian and the Massif Central domains. It is not yet clear if the Moldanubian zone underwent this Middle Devonian event (Vràna et al., 1995), but it seems that the major cordillera-building processes affecting this zone occurred in the Early Carboniferous, most likely due to intra-Hunic collisional events. However, the high-pressure rocks dated as Middle Silurian in Bavaria (427 $\pm 5 \mathrm{Ma}$; von Quadt and Gebauer, 1993) point to an active margin setting of the Moldanubian zone at that time (like the German Crystalline zone and the Leon domain), but not necessarily to collision. Therefore, the Moldanubian domain could also represent the same leading accretionary edge of the European Hunic terranes at that time and should have been located eastward of the Sudetes in prolongation of the Armorica (sensu lato) terrane (Fig. 4).

Similarly, the Ligerian cordillera of central France (Quenardel et al., 1991), extending up to the South Armorican domain (Le Corre et al., 1991), represents a large part of this Devonian Rheic suture zone and would also have been located east of the Sudetes. The metamorphism of the Massif Central was between 400 and $360 \mathrm{Ma}$, whereas poorly dated older high-pressure events could be related to Silurian subduction of the Rheic ocean. Lardeaux et al. (2001) proposed an oblique continent-arc collision for this region, a scenario similar to our Figure 4B. The high-pressure event of South Armorica (Champtoceaux complex) is dated as ca. 360 Ma (Ballèvre et al., 2000), including continent-derived protoliths of Early Ordovician age. These units were exhumed in the Visean and largely imbricated by thrusting and shearing during dextral movements in the Late Carboniferous. We have here the juxtaposition of two different domains, the Ligerian and Armorican, along a continental suture. Subduction-related granitic activity in Armorica was mainly Carboniferous and may correspond to the subduction of paleo-Tethys after the Middle Devonian event.

\section{Composite Middle Devonian event}

As shown in Figures 3 and 4, the Middle Devonian event would have been created in a different geodynamic context along the northern border of the Hun superterrane. From Portugal-Galicia to the Sudetes, this event corresponds to the consumption of a Rheno-Hercynian intervening terrane and midoceanic ridge by the Rheic accretionary prism. This situation can be extrapolated eastward in view of a potential continuation of the Rheno-Hercynian ocean toward the Black Sea and Caucasus. In northern Turkey, Kozur et al. (1999) and Kozur (1999) found remnants of a Carboniferous to Permian pelagic domain (Paphlagonia) formerly located just south of the Istanbul zone, which shows a development very similar to the Rheno-Hercynian domain (Göncüoglu and Kozur, 1998; Kozur et al., 2000). This Paphlagonian ocean could be extended eastward to the Dizi area of the western Great Caucasus (Adamia and Kutelia, 1987). The difference between the situation east and west of the Moesian promontory is that the final closure of these eastern pelagic realms did not take place before the Permian.

In the oriental part of the European Hunic terranes, we propose that the Ligerian-Moldanubian domain collided with an island-arc system derived from the subduction of the Asiatic ocean (Zonenshain et al., 1985), a time equivalent of the Rheic ocean. It was a large ocean connected to Panthalassa and developed numerous island arcs. It was proposed that the amalgamation of such island arcs (the Kipchak arc system) gave birth to the Kazakhstan plate (Şengör and Natl'in, 1996). In view of the convergence between Gondwana and the future continents composing Laurasia, a collision between an Asiatic island-arc system and the European Hunic terranes was probably unavoidable. We tentatively place domains such as the Sakarya zone of northern Turkey and part of the trans-Caucasus in this western Kipchak island-arc system. Elements of this arc would also be found in the LigerianMoldanubian cordillera, but most of this cordillera would most likely belong to the European Hunic terranes.

\section{Appalachians and Meguma-Meseta dilemma}

In the Appalachians the situation is less clear, although potentially simpler. It is less clear because a large part of the hinterland was lost in the opening of the Atlantic Ocean; it is apparently simpler because the mountain-building processes there appear to be a continuum of deformation (Keppie, 1989; Piqué and Skehan, 1992). Some correlations are proposed between, for example, the Meguma belt and the Ligerian cordillera of central France (Rast and Skehan, 1993), which 
would somewhat complicate the story. One of the problems to discuss here is the concept of tectonic phases, and, more precisely, the Acadian. This concept can only be used if it is supported by a consistent plate tectonic scheme; otherwise it is meaningless. The Acadian phase proper should be restricted to the docking of Avalonia to Laurentia, a docking generally accepted to be finished by Late Silurian time for east Avalonia but later for west Avalonia (Early Devonian; Friend et al., 2000). Therefore, younger events could correspond to the docking of Hun-like terranes to Laurentia, followed by the onset of subduction of paleo-Tethys under this continent. The docking of such terranes to Laurentia would be more or less simultaneous to the Middle Devonian event further west. Dallmeyer and Keppie (1987) have shown that the Meguma terrane was affected by an Early to Middle Devonian tectonometamorphic event, which could confirm the accretion of terranes at that time. The Meguma terrane was later intruded by Late Devonian granites, showing that subduction of paleo-Tethys under North America had already started at that time. Was the Meguma block accreted to North America in Middle Devonian time (Hun origin), or was it already part of Avalonia and detached from Avalonia and accreted again? These are main questions that are also relevant for the Moroccan Meseta, which is often considered to be part of the Meguma terrane. The absence of Silurian metamorphism in the Meguma and Meseta terranes is not a proof of their separation from Avalonia, because only the leading edge of Avalonia should have undergone such metamorphism. The leading northern edge of Meguma was affected by the Acadian orogeny (slaty cleavage dated as 405 Ma; Keppie, 1989), which would exclude a Hun origin, whereas its southern border remained a passive margin attached, in that case, to the Rheic ocean. Then it became an active margin, documented by Emsian deformation, extending southward to the Carolina region, where a tectonometamorphic event was dated as 340-360 Ma (Dallmeyer et al., 1986). A younger event, dated as ca. 268-315 Ma, marked the final collision with Gondwana.

A magmatic arc development is also known in the Meseta starting in the Tournaisian (Aouli granitoids, Oukemeni and Bourne, 1993) and postcollisional granites were emplaced until the Early Permian (Amenzou and Badra, 1996). However, the Meseta (e.g., Piqué, 1989) is characterized on its southeastern border by the development of a south-facing passive margin, with a prominent Early Devonian rift shoulder in the Rehamna region, passing to the southeast to Early to Middle Devonian deep-water deposits, therefore representing potential northern paleo-Tethyan marginal series characteristic of Hun-like terranes (see following). This margin was deformed during a Late Devonian tectonometamorphic phase (Huon et al., 1993), followed by the installation of an arc in Visean time, clearly marking the change from a passive to active margin setting. Late Visean (ca. $325 \mathrm{Ma}$ ) wild-flysch-type deposits, also present in the High Atlas (Jenny, 1988), mark the onset of deformation during the collision with Gondwana. Therefore, we can question the Meguma-Meseta connection, the Meguma being of Avalonian origin and the Meseta of Hun origin in our point of view. The limit between the two terranes could be located just offshore Morocco, west of the El Jadida escarpment, where low-grade metamorphic rock have been drilled (Kreuser et al., 1984).

We propose extending the Hun superterrane to Ecuador in order to include terranes, found now around the Gulf of Mexico area, that were detached from Gondwana in the Paleozoic (Dallmeyer, 1989; Keppie et al., 1996). Consequently, Hun-like terranes must have collided with North America. Potential candidates could be represented by the Carolina terrane (Horton et al., 1989) and related blocks, apparently separated from Laurentia by oceanic elements (Bel Air-Rising Sun terrane). Terranes implicated in the Alleghanian-Ouachita orogen are other potential candidates, like the Sabine block (Keller and Hatcher, 1999), as well as the Yucatan, Chortis, Mexican (Oaxaca, Arequipa-Antofalla), and other Central American terranes (Keppie et al., 1996).

\section{PALEO-TETHYS EVOLUTION}

The paleo-Tethys is more or less completely ignored by those who follow the classic Hercynian ideas; therefore it is important to present here the main lines of its geodynamic evolution. The opening of paleo-Tethys is relatively well defined on an Iranian transect (Alborz Range, north Iran; Stampfli, 1978; Stampfli et al., 1991, 2001a, 2001b) representing the southern Gondwanan margin of the eastern branch of the ocean. Late Ordovician to Early Devonian flood basalts, rift shoulder uplift in the Silurian, followed by the onset of thermal subsidence in the Devonian, point to a Late Ordovician-Silurian rifting phase. Seafloor spreading took place in the Late Silurian or Early Devonian and the rift shoulders were completely flooded in the Late Devonian, following regional thermal subsidence of the passive margin. From Late Devonian until Middle Triassic time a carbonate-dominated passive margin developed. A similar evolution is found in the Cimmerian part of Turkey (for details see references in Stampfli 1996; Göncüoglu and Kozur, 1998).

Toward the west, along the African domain, there are few data concerning the detachment of the European Hunic terranes from Gondwana. In the High Atlas of Morocco (e.g., Destombes, 1971), the Silurian unconformably overlies the Ordovician and presents locally, at its top, a conglomeratic sequence; the overlying Emsian-Eifelian sequence is locally very condensed and represented by open marine carbonates. This starvation event represents the onset of important thermal subsidence, which can be related to the drifting of either Armorica or the Meseta from Africa. On the basis of current information, it is unclear whether the opening took place simultaneously all along the Gondwana margin. Our preference is that the opening was earlier along the western branch of the ocean (Fig. 3). Farther west, along the Gondwana border, a major Carboniferous sedimentary wedge developed directly on the Precambrian basement along the Amazonian craton in Ecuador (Litherland et al., 1994); the absence of any sequence that could represent the early Paleozoic active or passive margin of this craton allows the opening of paleo- 
Tethys to be extended to the northern part of South America (as discussed herein about the Mexican terranes origin; Fig. 3).

The northern Hunic margin of the paleo-Tethys ocean is well represented in the middle part of the European Hunic terranes in the Carnic Alps (Schönlaub and Histon, 1999: Laufer et al., 2001), Tuscany, Sardinia, and the Alboran fragments (cf. Stampfli, 1996); it is also characterized by a Late Ordovician-Early Silurian clastic and often volcanic synrift sequence (Silurian flood basalts are also known in Sardinia and the Rif; Piqué, 1989). Rift-related thermal uplift, erosion, and tilting took place in Silurian time and are often (wrongly) related to the Taconic event (Tollmann, 1985). Open marine conditions started in the Silurian, being represented by a graptolites facies; a more general flooding took place in the Early Devonian and marked the onset of widespread thermal subsidence related to seafloor spreading.

The Saxo-Thuringian domain was part of the northern margin of paleo-Tethys before the lateral displacement of the Moldanubian zone to the south of it. Its autochthonous sequence (Falk et al., 1995) is marked by basin deepening in Silurian time, accompanied by lavas and tuffs in the Ludlow representing the synrift event, whereas pelagic Gedinnian to Givetian sediments represent the drift sequence.

On the northern margin, the Visean usually marks the onset of widespread flysch deposition, often accompanied by volcanic activity. We regard this major change as marking the general aggregation of the different terranes to Eurasia to form the Variscan cordillera; it also marks the onset of paleo-Tethys subduction and the transformation of the margin from passive to active, the flysch troughs usually representing forearc basins. Accretionary sequences related to this subduction are little known, most likely because important subduction erosion took place during the cordillera stage, as observed now along the South American active margin. Potential paleo-Tethyan accretionary sequences are located in the southern part of the Variscan orogen, and in all cases were metamorphosed and intruded by subsequent Late Carboniferous granites; in addition, they were usually involved in eo-Cimmerian and Alpine deformation. However, pelagic Devonian-Carboniferous to Early Triassic pelagic sediments of paleo-Tethyan origin are found in Sicily, the Dinarides, Hellenides, and Turkey (Karaburun) (Stampfli et al., 2002).

\section{CONCLUSIONS}

Deciphering the evolution of former circum-Gondwana terranes is a feasible enterprise; similar geological evolutions are found in these terranes. The explanation of the present complexity should not be sought in complex plate tectonic scenarios involving numerous oceanic realms; on the contrary, and in view of the similarities, a simple model is preferable. A single terrane model is also proposed for the accretion of all the Alaskan terranes (Johnston, 2001).

We propose continuous southward subduction of oceanic realms under the Gondwanan border, starting in the Late Neoproterozoic, which triggered the detachment of three main ter- ranes. First Avalonia in the Early Ordovician, then the European Hunic terranes in the Late Silurian, promptly followed by the eastern Hunic terranes in the Early Devonian.

The accretion of these terranes to Laurussia was complex. Whereas the Avalonia superterrane had a relatively simple evolution with a classical collision of an active and passive margin, a more complex scenario is necessary to explain the Variscan collage. In order to take into account similarities in the different parts of the European Hunic terranes, we propose that areas affected by the Middle Devonian high-pressure phase were located on the leading accretionary edge of these terranes, whereas areas not affected by this major eo-Variscan event were located on the paleo-Tethys margin of the terrane. This Middle Devonian eo-Variscan event is inferred to be related to accretion of buoyant material derived from Laurussia and subduction of a peri-Laurussian ocean, whereas farther east the event is related to collision with an island-arc system.

To explain the subsequent large-scale mixture of active and passive margins, important lateral displacements and rotations must be invoked: most who study Hercynian ideas would agree with this proposition (e.g., Matte et al., 1990; Edel, 2000, 2001), but the majority would place these translations in a context of continent-continent collision. We propose that these took place during the displacement of terranes along a still-active margin, the translations being accompanied by transtensional and tranpressional events leading to the opening of Gulf of California-type oceans and in other places to the buildup of cordilleras.

During the growth of the late Carboniferous cordillera, two types of geological evolution developed. The westward one is toward a continent-continent collision where the accreted terranes got squeezed between Laurussia and Gondwana (this is the prevailing scenario for the Alleghanian regions), whereas eastward, subduction continued with a general rollback of the paleo-Tethyan slab. This, in turn, generated the opening of numerous backarc basins and oceans, starting in the Early Permian and lasting until the Middle Triassic closure of the paleo-Tethys oceanic domain.

Postcollisional Permian-Carboniferous granites, for example found in Morocco (e.g., Amenzou and Badra, 1996), should be related to slab detachment when major crustal attenuation through generalized extension is not documented. In other western European regions, postcollisional Permian-Carboniferous granites should be related to slab detachment and/or the collapse of the cordillera, but not to postcollisional processes, the final collision being far distant in time and space. The final closure of paleo-Tethys from Sicily to the Caucasus took place during the eo-Cimmerian cycle, and the closure of backarc oceans issued from the paleo-Tethys slab rollback took place only in Cretaceous time (Stampfli et al., 2001b).

We hope that our provocative suggestions will trigger a new round of discussion for the coming years; more field data should be gathered for a better approach of Variscan history, and paleoreconstructions on a larger scale should be included. 


\section{ACKNOWLEDGMENTS}

We thank the conveners of the Basement Tectonics 15 Galicia 2000 congress (R. Arenas, Madrid; F. Diaz Garcia, Oviedo; J.R. Martinez-Catalan, Salamanca) for providing an ideal environment for stimulating discussion, encouraging us to publish this paper, and for encouraging remarks. We also thank J. Mosar, with whom these reconstructions were initiated, and H. Kozur for sharing key information on Paleozoic paleogeography. Our warm thanks to Dave Gee (Uppsala) for his engaged criticism and a readable English version, and we thank an anonymous reviewer for constructive suggestions.

\section{REFERENCES CITED}

Abati, J., Dunning, G.R., Arenas, R., Díaz García, F., Gonzáles Cuadra, P., Martínez Catalán, J.R., and Andonaegui, P., 1999, Early Ordovician orogenic event in Galicia (NW Spain): evidence from U-Pb ages in the uppermost unit of the Ordenes Complex: Earth and Planetary Science Letters 165, p. 213-228.

Acquafredda, P., Lorenzoni, S., and Zanettin Lorenzoni, E., 1994, Paleozoic sequences and evolution of the Calabrian-Peloritan Arc (Southern Italy): Terra Nova, v. 6, p. 582-594.

Adamia, S., and Kutelia, Z., 1987, paleo-Tethys-Tethys: continuous developement: IGCP, v. 5, newsletter 7, p. 109-115.

Amenzou, M., and Badra, L., 1996, Les granites d'Azegour et de Brikiine (Maroc): implications génétique d'après la typologie des zircons: Comptes Rendus de l'Académie des Sciences de Paris, Série II, v. 323, no. 3, p. 213-220.

Anthes, G., and Reischmann, T., 2001, Timing of granitoid magmatism in the eastern mid-German crystalline rise: Journal of Geodynamics, v. 31, p. 119-143.

Arenas, R., Díaz García, F., Martínez Catalán, J.R., Abati, J., González Cuadra, P., Andonaegui, P., Gonzáles del Tanago, J., Rubio Pascual, F., Castiñeiras, P., and Gomez Barreiro, J., 2000, Structure and evolution of the Ordenes Complex: A Coruna, Spain, Basement Tectonics 15, Pre-Conference Field Trip.

Ballèvre, M., Bosse, V., Capdevilla, R., de Jong, K., Féraud, G., Guerrot, C., Peucat, J.J., and Ruffet, G., 2000, Structure and thermo chronology of the Champtoceaux complex (France): A key for Ibero-Armorican correlation., in Basement tectonics 15: A Coruna, Spain, p. 52-55.

Capuzzo, N., and Bussy, F., 2000, High precision dating and origin of synsedimentary volcanism in the late Carboniferous Salvan-Dorénaz basin (Aiguilles-Rouges massif, western Alps: Schweizerische Mineralogische und Petrographische Mitteilungen, v. 80, p. 147-167.

Catalano, R., Distefano, P., and Kozür, H., 1988, New results in the Permian and Triassic stratigraphy of western Sicily with special reference to the section at Torrente San Calogero, SW of Pietra di Salome (Sosio valley): Società Geologica Italiana, v. Atti del 74 Congresso Nazionale, v. A, p. 119-125.

Cortesogno, L., Dallagiovanna, G., Gaggero, L., and Vanossi, M., 1993, Elements of the Paleozoic history of the Ligurian Alps, in von Raumer, J.F., and Neubauer, F., eds., Pre-Mesozoic geology of the Alps: Berlin, Springer Verlag, p. 257-277.

Crowley, Q.G., Floyd, P.A., Stodra, V., Winchester, J.A., and Holland, J.G., 2000, The Marianske-Lazne complex, remnants of a subducted early Paleozoic seaway: Basement Tectonics 15, A Coruña, Spain, Program and Abstracts, p. 86-89

Dallmeyer, R.D., 1989, Contrasting accreted terranes in the southern Appalachian orogen and Atlantic-Gulf Coastal Plains and their correlations with West African sequences, in Dallmeyer, R.D., ed., terranes in the circum-Atlantic Paleozoic orogens: Boulder, Colorado, Geological Society of America Special Paper 230, p. 247-267.
Dallmeyer, R.D., and Keppie, J.D., 1987, Polyphase late Paleozoic tectonothermal evolution of the southwestern Meguma terrane, Nova Scotia: Evidence from ${ }^{40} \mathrm{Ar} /{ }^{39} \mathrm{Ar}$ mineral ages: Canadian Journal of Earth Science, v. 24, p. $1242-1254$.

Dallmeyer, R.D., and Martínez García, E., 1990, Pre-Mesozoic geology of Iberia: Berlin, Springer-Verlag, $416 \mathrm{p}$.

Dallmeyer, R.D., Franke, W., and Weber, K., 1995, Pre-Permian geology of central and eastern Europe: Berlin, Springer-Verlag, 604 p.

Dallmeyer, R.D., Wright, J.E., Secor Jr, D.T., and Snoke, A.W., 1986, Character of the Alleghanian orogeny in the southern Appalachians: II: Geochronological constraints on the tectonothermal evolution of the eastern Piedmont in South Carolina: Geological Society of America Bulletin, v. 97, p. 1329-1344.

Dean W.T., Monod, O., Rickards, R.B., Demir, O., and Bultynck, P., 2000, Lower Paleozoic stratigraphy and palaeontology, Karadere-Zirze area, Pontu Mountains, northern Turkey: Geological Magazine, 137, p. 555-582.

Destombes, J., 1971, L'Ordovicien du Maroc: Essai de synthèse stratigraphique: Mémoires du Bureau de Recherches Géologiques et Minières Orléans, v. 73 , p. $237-263$.

Díaz García, F., Arenas, R., Martínez Catalán, J.R., González del Tánago, J., and Dunning, G.R., 1999, Tetctonic evolution of the careon ophiolite (northwest Spain): A remnant of the oceanic lithosphere in the Variscan belt: Journal of Geology, v. 107, p. 587-605.

Dvorak, J., 1995, ChapterVIII.B.1 Stratigraphy, in Dallmeyer, R.D., Franke, W., and Weber, K., eds., Pre-Permian geology of Central and Eastern Europe: Berlin Heidelberg New York, Springer-Verlag, p. 478-490.

Edel, J.B., 2000, Hypothèse d'une ample rotation horaire tardi-varisque en bloc Maures-Estérel-Corse-Sardaigne: Géologie de la France, v. 1, p. 3-19.

Edel, J.B., 2001, The rotations of the Variscides during the Carboniferous collision: paleomagnetic constraints from the Vosges and the Massif Central (France): Tectonnophysics, v. 332, p. 69-92.

Eguiluz, L., Gil Ibarguchi, J.I., Abalos, B., and Apraiz, A., 2000, Superposed Hercynian and Cadomian orogenic cycles in the Ossa-Morena zone and related areas of the Iberian Massif: Geological Society of America Bulletin, v. 112, p. 1398-1413.

Falk, F., Franke, W., and Kurze, M., 1995, Chapter V.B.1 Stratigraphie, in Dallmeyer, R.D., Franke, W., and Weber, K., eds., Pre-Permian geology of Central and Eastern Europe: Berlin Heidelberg New York, Springer-Verlag, p. 221-234.

Faure, M., Leloix, Ch., Roig, J.-Y., 1997, L'évolution polycyclique de la chaîne hercynienne: Bulletin de la Société Géologique de France, 168, p. 695-705.

Fernández-Suárez, J., Gutiérrez-Alonso, G., Jenner, G.A., Tubrett, M.N., 2000, New ideas on the Proterozoic-early Paleozoic evolution of NW Iberia: Insights from U-Pb detrital zircon ages: Precambrian Research 102, p.185-206.

Findley, R.H., 1998, The Song Ma anticlinorium, northern Vietnam: The structure of an allochthonous terrane containing an early Paleozoic island arc sequence: Journal of Asian Earth Sciences, v. 15, no. 6, p. 453-464.

Flick, H., Pfefferkorn, H.W., and Schmidt, J., 1988, Presence of land-plants on a volcanic island in a Devonian sea (Rhenish mountains, West Germany): Review of Paleobotany and Palynology, v. 56, p. 177-181.

Floyd, P.A., 1995, Chapter III.B.3: Igneous activity, in Dallmeyer, R.D., Franke, W., and Weber, K., eds., Pre-Permian geology of Central and Eastern Europe: Berlin Heidelberg New York, Springer-Verlag, p. 59-81.

Flügel, H.W., 1990 Das voralpine Basement im Alpin-Mediterranen BeltÜberblick und Problematik: Jahrbuch der Geologischen Bundes Anstalt, v. 133 , p. $181-221$.

Foster, D.A., and Gray, D.R., 2000, Evolution and structure of the lachlan fold belt (orogen) of Eastern Australia: Annual Review of Earth and Planetary Sciences, v. 28, p. 47-80.

Franke, W., 1989, Variscan Plate tectonics in Central Europe-Current ideas and open questions: Tectonophysics, 169, p.221-228.

Franke, W., 1992, Phanerozoic structures and events in Central Europe, in Blundell, D., Freeman, R., and Mueller, St., eds, A continent revealed: Cambridge, Cambridge University Press 1992, pp 164-180. 
Franke, W., 1995, Chapter III.B.1: Stratigraphy, in Dallmeyer, R.D., Franke, W., and Weber, K., eds., Pre-Permian geology of Central and Eastern Europe: Berlin Heidelberg New York, Springer-Verlag, p. 33-49.

Franke, W., 2000, The mid european segment of the Variscides: tectono-stratigraphic units, terrane boundaries and plate tectonic evolution, in Franke, W., Haak, V., Oncken, O., and Tanner, D., eds., Orogenic processes: Quantification and modelling in the Variscan belt: Geological Society of London Special Publication 179, p. 35-62.

Franke, W., Kreuzer, H., Okrusch, M., Schüssler, U., and Seidel, E., 1995, ChapterV.C.1: Stratigraphy, structure, and igneous activity, in Dallmeyer, R.D., Franke, W., and Weber, K., eds., Pre-Permian geology of Central and Eastern Europe: Berlin Heidelberg New York, Springer-Verlag, p. 277-294.

Franke, W., Haak, V., Oncken, O., Tanner, D., 2000, Orogenic processes: Quantification and modelling in the Variscan belt: Geological Society Special Publication 179, 459p.

Friend, P.F., Williams, B.P.J., Ford, M., and Williams, E.A., 2000, Kinematics and dynamics of Old Red Sandstone basins, in Friend, P.F., and Williams, B.P.J., eds., New perspectives on the Old Red Sandstone: Geological Society of London Special Publication 180, p. 29-60.

Frisch, W., and Neubauer, F., 1989, Pre-Alpine terranes and tectonic zoning in the eastern Alps, in Dallmeyer, R.D., ed., Terranes in the circum-Atlantic Paleozoic orogens: Boulder, Colorado, Geological Society of America Special Paper 230, p. 91-114.

Ghienne, J.F., Bartier, D., Leone, F., and Loi, A., 2000, Caractérisation des horizons manganésifères de l'Ordovicien supérieur de Sardaigne: Relation avec la glaciation fini-ordovicienne: Comptes Rendus de l'Académie des Sciences de Paris, v. 331, p. 257-264.

Giorgis, D., Thélin, P., Stampfli, G.M., and Bussy, F., 1999, The Mont-Mort metapelites: Variscan metamorphism and geodynamic context (Briançonnais basement, western Alps, Switzerland): Schweizerische Mineralogische und Petrographische Mitteilungen, v. 79, p. 381-398.

Göncüoglu, C., and Kozur, H., 1998, Remarks to the pre-Variscan development in Turkey: Schr. Staatl. Mus. Min. Geol. Dresden, v. 9, p. 137-138.

Gil Ibarguchi, J.I., Ábalos, B., Azcárraga, J., Mendia, M., Puelles, P., 2000, A petrological and structural excursion through the high-grade/high-pressure allochthonous units of the Cabo Ortegal complex (NW Spain): Basement Tectonics 15, mid-Conference field trip, A Coruña, Spain.

Hatcher, R.D., 1983, Basement massifs in the Appalachians: Their role in deformation during the Appalachian orogenies: Geological Journal, v. 18, p. $255-265$.

Heinisch, H., Schätz, M., Bachtadse, V., and Tait, J., 2000, Paleomagnetic and sedimentological constraints on the position of Northern Graywacke Zone, Eastern Alps within the Paleozoic terrane assemblage: Schiften der AlfredWegener-Stiftung Terra Nostra, v. 2000, no. 1, p. 54.

Hoffman, P.F., 1991, Did the breakout of Laurentia turn Gondwanaland inside out?: Science, v. 252, p. 1409-1412.

Horton, J.W., Drake, A.A., and Rankin, D.W., 1989, Tectonostratigraphic terranes and their Paleozoic boundaries in the central and southern Appalachians, in Dallmeyer, D., ed., Terranes in the circum-Atlantic Paleozoic orogens: Boulder, Colorado, Geological Society of America Special Paper 230, p. 213-245.

Huon, S., Cornée, J.J., Piqué, A., Rais, N., Clauer, N., Liewig, N., and Zayane, R., 1993, Mise en évidence d'un métamorphisme statique d'âge triassicoliasique lié à l'ouverture de l'Atlantique: Bulletin de la Société Géologique de France, v. 164, no. 2, p. 165-176.

Hutchison, C.S., 1989, Geological evolution of South-East Asia: Clarendon press Oxford, Oxford Monographs on Geology and Geophysics, 368 p.

Jenny, J., 1988, Carte géologique du Maroc au 1:100,000, feuille Azilal, Mémoire explicatif: Notes et Mémoires du Service géologique du Maroc, v. 399 bis, 104 p.

Johnston, S.T., 2001, The Great Alaskan Terrane wreak: Reconciliation of paleomagnetic and geological data in the northern Cordillera: Earth and Planetary Science Letters, v. 193, p. 259-272.

Keller, G.R., and Hatcher, R.D., 1999, Some comparisons of the structure and evolution of the southern Appalachian-Ouachita orogen and por- tions of the Trans-European Suture Zone region: Tectonophysics, v. 314, p. 43-68.

Keppie, J.D., 1989, Northern Appalachian terranes and their accretionary history, in Dallmeyer, D., ed., Terranes in the circum-Atlantic Paleozoic orogens: Boulder, Colorado, Geological Society of America Special Paper 230, p. 159-192.

Keppie, J.D., 1994, Pre-Mesozoic geology in France: Berlin-Heidelberg-New York, Springer Verlag, 514 p.

Keppie, J.D., Dostal, J., Murphy, J.B., and Nance, R.D., 1996, terrane transfer between Laurentia and western Gondwana in the early Paleozoic: constraints on global reconstructions, in Nance, R.D., and Thompson, M.D., eds., Avalonian and related peri-Gondwana terranes of the circum-Atlantic: Boulder, Colorado, Geological Society of America Special Paper 304, p. 369-380.

Khain, V.E., 1994, Geology of Northern Eurasia (Ex-USSR): Beiträge zur regionalen Geologie der Erde, v. 24, p. 346-385.

Klootwijk, C., 1996, Phanerozoic configurations of Greater Australia : evolution of the North West Shelf: Australian Geological Survey Organisation, Record 1996/51-1996/53.

Kossmat, F., 1927, Gliederung des varistischen Gebirgsbaues: Abhandlungen der sächsischen geologischen Landes Anstalt 1, p. 1-39.

Kozur, H., 1997, First discovery of Muellerisphaerida (inc. sedis) and Eoalbaillella (Radiolaria) in Turkey and the age of the siliciclastic sequence (clastic series) in Karaburun peninsula: Freiberger Forschungsheft, v. C 466, p. $33-59$.

Kozur, H., 1998, The age of the siliciclastic series ("Karareis formation") of the western Karaburun peninsula, western Turkey: Paleontologia Polonica, v. 58 , p. $171-189$.

Kozur, H., 1999, Permian development in the western Tethys, in Shallow Tethys 5, Chiang Mai: Department of Geological Sciences, University of Chiang Mai, p. 101-135.

Kozur, H.W., Senel, M., and Tekin, K., 1998, First evidence of Hercynian Lower carboniferous deep-water sediments in the Lycian nappes, SW Turkey: Geologia Croatica, v. 51, no. 1, p. 15-22.

Kozur, H., Aydin, M., Demir, O., and Yakar, H., 1999, Geological evolution of middle Pontide area (northern Turkey) and eastward continuation of the Meliata-Hallstatt ocean: Geologica Carpathica, v. 50, p. 154-155.

Kozur, H., Aydin, M., Demir, O., Yakar, H., Göncüoglu, M.C., and Kuru, F., 2000, New stratigraphic and palaeogeographic results from the Palaeozoic and Early Mesozoic of the Middle Pontides (Northern Turkey) in the Azdavay, Devrekani, Küre and Inebolu areas: Implications for the Carboniferous-Early Cretaceous geodynamic evolution and some related remarks to the Karakaya oceanic rift basin: Geologia Croatica, v. 53/2, p. 209-268.

Krahl, J., Kauffmann, G., Richter, D., Kozur, H., Möller, I., Förster, O., Heinritzi, F., and Dornsiepen, U., 1986, Neue Fossilfunde in der Phyllit-Gruppe Ostkretas (Griechenland): Zeitschrift der deutschen geologischen Gesellschaft, v. 137, p. 523-536.

Kreuser, H., Muller, P., Reinecke, T., and Wissmann, G., 1984, Petrography and $\mathrm{K}$-Ar dating of the Mazagan granodiorite, in Hinz, K., Winterer, E.L., and others, eds., Initial Reports of the Deep Sea Drilling Project, Leg 9, holes 554A and B: Washington, D.C., U.S. Government Printing, p. 543-549.

Krs, M., and Pruner, P., 1999, To the paleomagnetic investigations of paleogeography of the Barrandian terrane, Bohemian massif: Acta Universitatis Carolinae-Geologica, v. 43, p. 519-522.

Lardeaux, J.M., Ledru, P., Daniel, I., and Duchene, S., 2001, The Variscan French Massif Central-A new addition to the ultrahigh pressure metamorphic "club": Exhumation processes and geodynamic consequences: Tectonophysics, v. 332, p. 143-167.

Laüfer, A.L., Hubich, D., and Loeschke, J., 2001, Variscan geodynamic evolution of the Carnia Alps (Austria/Italy): International Journal of Earth Sciences, v. 90, p. 855-870.

Le Corre, C., Auvray, B., Ballevre, M., and Robardet, M., 1991, Le Massif Armoricain, in Piqué, A., ed., Les massifs anciens de France: Sciences Géologiques (Strasbourg) Bulletin, p. 31-104. 
Linnemann, U., Buschmann, B., 1995, Die cadomische Diskordanz im Saxothuringikum (oberkambrisch-tremadocische overlap-Sequenzen): Zeitschrift für geologische Wissenschaften 23, p. 707-727.

Litherland, M., Aspden, J.A., and Jemielita, R.A., 1994, The metamorphic belts of Ecuador: Overseas Memoir of the British Geological Survey, 147 p.

Marcos, A., Fernandez Rodriguez, F.J., and Llana Funez, S., 2000, Structure of the Cabo Ortegal Nappe, in Basement tectonics 15, A Coruna, p. 1-59.

Martínez Catalán, J.R., Arenas, R., Díaz García, F., Abati, J., 1997, Variscan accretionary complexes of northwest Iberia: terrane correlation and succession of tectonothermal events: Geology, 25, p. 1103-1106.

Martínez Catalán, J.R., Arenas, R., Díaz García, F., Abati, J., 1999, Allochthonous units in the Variscan belt of NW Iberia: in Sinha, A.K., ed., Basement Tectonics 13: Dordrecht, Netherlands, Kluver Academic Publishers: p. 65-84.

Matte, P., 1991, Accretionary history and crustal evolution of the Variscan belt in Western Europe: Tectonophysics 180, p. 309-338.

Matte, P., 1998, Continental subduction and exhumation of HP rocks in Paleozoic orogenic belts: Uralides and Variscides: Geologiska Forhandlinger a Föreninger 120, 209-222.

Matte, P., Maluski, H., Rajlich, P., Franke, W., 1990, Terrane boundaries in the Bohemian massif: result of large-scale Variscan shearing: Tectonophysics 177, p.151-170.

Mingram, B., 1998, The Erzgebirge, Germany-A subducted part of northern Gondwana: geochemical evidence for repetition of early Paleozoic metasedimentary sequences in metamorphic thrust units: Geological Magazine 135 , p. $785-801$.

Meisl, S., 1995, Chapter III.C.3: Igneous activity, in Dallmeyer, R.D., Franke, W., and Weber, K., eds., Pre-Permian geology of Central and Eastern Europe: Berlin Heidelberg New York, Springer-Verlag, p. 118-137.

Meng, Q.-R., and Zhang, G.-W., 1999, Timing of collision of the north and south China blocks: Controversy and reconcialation: Geology, v. 27, no. 2, p. 123-126.

Monod, O., Ghienne, J.-F., Dean, W.T., Kozlu, H., Günay, Y., Paris, F., Le Hérissé, A., and Rickards, R.B., 2002, Ordovician glaciation in southern Turkey, in 1st international symposium of the Faculty of Mines (ITü) on Earth Science and Engineering, Istanbul, p. 82.

Nesbor, H.D., Buggisch, W., Flick, H., Horn, M., and Lippert, H.J., 1993, Vulkanismus im Devon des Rhenohercynikums: Geologische Abhandlungen Hessen, v. 98, p. 3-87.

Neubauer, F., and Handler, R., 2000, Variscan orogeny in the Eastern Alps and Bohemian Massif: How do these units correlate: Mitteilungen der Österreichischen Geologischen Gesellschaft, v. 92, p. 35-59

Oliveira, J.T., and Quesada, C., 1998, A comparison of stratigraphy, structure and paleogeography of the South-Portuguese zone and south-west England: Geoscience in South-West England, v. 9, p. 141-150.

Ordoñez Casado, B., 1998, Geochronological studies of the pre-Mesozoic basement of the Iberian Massif: The Ossa Morena zone and the allochthonous complexes within the Central Iberian zone: Eidgenössische Technische Hochschule Zürich, n. 12,940, 235 p.

Oukemeni, D., and Bourne, J.H., 1993, Études géochimique des granitoides du pluton d'Aouli, Haute Moulouya, Maroc: Journal of African Earth Sciences, v. 17, p. 429-443.

Paris, F., and Robardet, M., 1990, Early Paleozoic paleogeography of the Variscan regions: Tectonophysics, v. 177, p. 193-213.

Pin, Ch., 1990, Variscan oceans: Ages, origins and geodynamic implications inferred from geochemical and radiometric data: Tectonophysics 177, p. $215-227$.

Pin, C., Paquette, J.L., Gil Ibarguchi, J.I., Santos Zalduegui, J.F., Rodríguez Aller, J., and Ortega Cuesta, L.A., 2000, Geochronological and geochemical constraints on the origin of ophiolitic units from the northwestern Iberian massif, in Variscan Appalachian Dynamics: the building of the upper Paleozoic basement. Basement tectonics 15, La Coruña, p. 146-147.

Piqué, A., 1989, Variscan terranes in Morocco, in Dallmeyer, R.D., ed., Terranes in the circum-Atlantic Paleozoic orogens: Boulder, Colorado, Geological Society of America Special Paper 230, p. 115-129.
Piqué, A.,and Skehan, J.W., 1992, Late Paleozoic orogenesis in western Africa and eastern north America: closure of the Theic ocean: Tectonics, v. 11, no. 2, p. 392-404.

Quenardel, J., Santallier, D., Burg, J., Bril, H., Cathelineau, M., and Marignac, C., 1991, Le Massif Central, in Piqué, A., ed., Les massifs anciens de France: Sciences Géologiques (Strasbourg) Bulletin, p. 105-206.

Rast, N., and Skehan, J.W., 1993, Mid-Paleozoic orogenesis in the North Atlantic: the Acadian orogeny: Boulder, Colorado, Geological Society of America Special Paper 275, p. 1-25.

Reischmann, T., and Anthes, G., 1996, Geochronology of the mid-German crystalline rise west of the River Rhine: Geologische Rundschau, v. 85, p. 761-774.

Robardet, M., 1996, Early Paleozoic palaeogeography of North-Gondwanan Europe, in Baldis, B., and Aceñolaza F.G., eds, Early Paleozoic evolution in NW Gondwana: Serie correlación geologica 12, p. 167-180.

Robardet, M., 2000, An alternative approach to consider the Variscan Belt in SW Europe: The pre-orogenic palaeogeographical constraints: Basement Tectonics 15, A Coruna, Spain, Program and Abstracts, p. 23-26.

Robardet, M., Paris, F., and Racheboeuf, P.R., 1990, Paleogeographic evolution of southwest Europe during early Paleozoic time, in McKerrow, W.S., and Scotese, C.R., eds., Paleozoic paleogeography and biogeography: Boulder, Colorado, Geological Society of America Memoir 12, p. 411419.

Robardet, M., Verniers, J., Feist, R., and Paris, F., 1994, Le Paléozoique antévarisque de France, contexte paléogéographique et géodynamique: Géologie de la France, v. 3, p. 3-31.

Ruttner, A.W., 1993, Southern borderland of Triassic Laurasia in NE Iran: Geologische Rundschau, v. 82, p. 110-120.

Sandeman, H.A., Chen, Y., Clark, A.H., and Farrar, E., 1995, Constraints on the $P-T$ conditions and age of emplacement of the Lizard ophiolite Cornwal: Amphibole-plagioclase thermobarometry and $\mathrm{Ar} / \mathrm{Ar}$ geochronology of basal amphibolites: Canadian Journal of Earth Science, v. 32, p. 261-272.

Schätz, M., Bachtadse, V., Tait, J., and Soffel, H., 1997, Paleomagnetic results from lower Devonian sediments of the southern Alps: Schiften der AlfredWegener-Stiftung Terra Nostra, v. 97/5, p. 152-155.

Schaltegger, U., Nägler, Th. N., Corfu, F., Maggetti, M., Galetti, G., and Stosch, H.G., 1997, A Cambrian island arc in the Silvretta nappe: Constraints from geochemistry and geochronology: Schweizerische Mineralogisch Petrographische Mitteitlungen, 77. p. 351-359.

Schönlaub, H.P., and Histon, K., 1999, The Paleozoic evolution of the southern Alps: Mitteilungen der Österreichischen Geologischen Gesellschaft, v. 92, p. $15-34$.

Schulmann, K., Ledru, P., Autran, A., Melka, R., Lardeux, J.M., Urban, M., Lobkowicz, M., 1991, Evolution of nappes in the eastern margin of the Bohemian Massif: A kinematic interpretation: Geologische Rundschau 80, p. 73-92.

Şengör, A.M.C., 1979, Mid-Mezozoic closure of Permo-Triassic Tethys and its implications: Nature, v. 279, p. 590-593.

Şengör, A.M.C., 1984, The Cimmeride orogenic system and the tectonics of Eurasia: Boulder, Colorado, Geological Society of America Special Paper 195 , p. 82.

Şengör, A.M.C., and Natl'in, B.A., 1996, Paleotectonics of Asia: fragments of a synthesis, in Yin, A., and Harrison, M., eds., The tectonic Evolution of Asia: Cambridge, Cambridge University press, p. 443-486.

Seston, R., Winchester, J.A., Piasecki, M.A.J., Crowley, Q.G., and Floyd, P.A., 2000, A structural model for the western-central Sudetes; a deformed stack of Variscan thrust sheets: Journal of the Geological Society of London, v. 157 Part 6, p. 1155-1167.

Stampfli, G.M., 1978, Étude géologique generale de l'Elbourz oriental au sud de Gonbad-e-Qabus (Iran NE) [PhD. Thesis]: University Genève, , no. 1868,329 p.

Stampfli, G.M., 1996, The Intra-Alpine terrain: A paleo-Tethyan remnant in the Alpine Variscides: Eclogae Geologicae Helvetiae, v. 89, no. 1, p. 13-42.

Stampfli, G.M., 2000, Tethyan oceans, in Bozkurt, E., Winchester, J.A., and Piper, J.D.A., eds., Tectonics and magmatism in Turkey and surrounding 
area: London, Geological Society of London Special Publication 173, p. $163-185$.

Stampfli, G.M., and Borel, G.D., 2002, A plate tectonic model for the Paleozoic and Mesozoic: Earth and planetary Science Letters, v. 196, p. 17-33.

Stampfli, G.M., Marcoux, J., and Baud, A., 1991, Tethyan margins in space and time, in Channell, J.E.T., Winterer, E.L., and Jansa, L.F., eds., Paleogeography and paleoceanography of Tethys: Palaeogeography, Palaeoclimatology, Palaeoecology, p. 373-410.

Stampfli, G.M., Borel, G., and von Raumer, J., 2000, terrane accretion in the Variscan domain: Basement Tectonics 15, A Coruna, Spain, Program and Abstracts, p. 167-169.

Stampfli, G.M., Mosar, J., Favre, P., Pillevuit, A., and Vannay, J.-C., 2001a, Permo-Mesozoic evolution of the western Tethyan realm: The Neotethys/East-Mediterranean connection, in Ziegler, P.A., Cavazza, W., Robertson, A.H.F.R., and Crasquin-Soleau, S., eds., Peri-Tethys Memoir 6: Peritethyan rift/wrench basins and passive margins, Mémoire Musée National Histoire Naturelle, v. 186, p. 51-108.

Stampfli, G.M., Borel, G., Cavazza, W., Mosar, J., and Ziegler, P.A., 2001b, The paleotectonic atlas of the Peritethyan domain: European Geophysical Society (CD ROM).

Stampfli, G.M., Vavassis, I., De Bono, A., Rosselet, F., Matti, B., and Bellini, M., 2002, Remnants of the Paleotethys oceanic suture-zone in the western Tethyan area, in Cassinis, G., and Decandia, F.A., eds., Stratigraphic and structural evolution on the Late Carboniferous to Triassic continental and marine successions in Tuscany (Italy): Regional Reports and General Correlation, Bolletino della Società Geologica Italiana, special issue, (in press).

Stille, H., 1951, Das mitteleuropäische Variszische Grundgebirge im Bilde des gesamteuropäischen: Geologisches Jahrbuch Beihefte, v. 2, p. 1-138.

Stipska, P., Schulmann, K., Kroener, A., 1998, Role of Cambrian-Ordovician rifting in Variscan collision at the NE margin of the Bohemian Massif: Acta Universitatis Carolinae Geologica, v. 42, p. 343-344.

Suess, E., 1909, Das Antlitz der Erde: Braumüller Wien.

Tait, J., Schätz, M., Bachtadse, V., Soffel, H., 2000, Palaeomagnetism and Paleozoic palaeogeography of Gondwana and European terranes, in Franke, W., Haak, V., Oncken, O., Tanner, D., eds., Orogenic processes: Quantification and modelling in the Variscan belt: London, Geological Society of London Special Publication 179, p. 21-34.

Thiéblemont, D., Marcoux, E., Tegyey, M., and Leistel, J.-M., 1994, Genèse de la province pyriteuse sud-ibérique dans un paléo-prisme d'accrétion? Arguments pétrologiques: Bulletin de la Société géologique de France, v. 165, p. $407-423$.

Tollmann, A., 1985, Geologie von Österreich, Band II: Wien, Franz Deuticke, $710 \mathrm{p}$.

Torsvik, T.H., and Smethurst, M.A., 1994, Geographic mapping and paleoreconstruction package (GMAP): Software description and examples of paleoreconstructions: Norges geologiske unders $\emptyset$ kelse (NGU).

Torsvik, T.H., and Eide, E.A., 1998, Phanerozoic paleogeography and geodynamics with Atlantic details: Norges geologiske unders $\varnothing$ kelse (NGU) report, v. $98.001,82 \mathrm{p}$.

Torsvik, T.H., and Smethurst, M.A., 1999, Plate tectonic modelling: Virtual reality with GMAP: Computers \& Geosciences, v. 25, p. 395-402.

Torsvik, T.H., Smethurst, M.A., Van der Voo, R., Trench, A., Abrahamsen, N., and Halvorsen, E., 1992, Baltica. A synopsis of Vendian-Permian paleomagnetic data and their paleotectonic implications: Earth-Science Reviews, v. 33, p. 133-152.

Unrug, R., 1997, Rodinia to Gondwana: the geodynamic map of Gondwana Supercontinent assembly: GSA Today v. 7, no. 1, p. 1-6

Van der Voo, R., 1993, Paleomagnetism of the Atlantic, Tethys, and Iapetus oceans: Cambridge, Cambridge University Press, $411 \mathrm{p}$

Vavassis, I., De Bono, A., Stampfli, G.M., Giorgis, D., Valloton, A., and Amelin, Y., 2000, U-Pb and Art-Ar geochronological data from the Pelagonian basement in Evia (Greece): Geodynamic implications for the evolution of paleo-Tethys: Schweizerische Mineralogische und Petrographische Mitteilungen, v. 80, p. 21-43. von Quadt, A., and Gebauer, D., 1993, Sm-Nd and U-Pb dating of eclogites and granulites from the Oberpfalz, NE Bavaria, Germany: Chemical Geology, v. 109 , p. 317-339.

von Raumer, J.F., 1998, The Paleozoic evolution in the Alps-From Gondwana to Pangea: Geologische Rundschau 87, p. 407-435.

von Raumer, J.F., and Neubauer, F., 1993, The Pre-Mesozoic geology in the Alps: Springer, Heidelberg, $671 \mathrm{p}$.

von Raumer, J.F., and Neubauer, F., 1994, The Paleozoic evolution of the Alps. Schweizerische Mineralogisch Petrographische Mitteilungen v. 74, p. 459-467.

von Raumer, J.F., and Stampfli, G.M., 2000, Comparing the peri-Gondwanan evolution of pre-Variscan domains: Basement Tectonics 15, A Coruña, Spain, Program and Abstracts, p. 18-20.

von Raumer, J., Stampfli, G.M., and Mosar, J., 1998, From Gondwana to Pangea-An Alpine point of view: Terra Nostra, v. Schriften der A. Wegener Stiftung 98/2, no. Giessen, p. 154-156.

von Raumer, J.F., Stampfli, G.M., Borel, G., and Bussy, F., 2002, The Organization of pre-Variscan basement areas at the Gondwana margin: International Journal of Earth Sciences, v. 91, p. 35-52.

Vràna, P., Blümel, P., and Petrakakis, K., 1995, Chapter VII.C.4: Metamorphic evolution, in Dallmeyer, R.D., Franke, W., and Weber, K., eds., Pre-Permian geology of Central and Eastern Europe: Berlin Heidelberg New York, Springer-Verlag, p. 453-466.

Walliser, O., 1981, The geosynclinal development of the Rheinische Schiefergebirge (Rheno-Hercynian Zone of the Variscides; Germany), in Zwart, H.J., and Dornsiepen, U.F., eds., The Variscan Orogen in Europe, Geologie en Mijnbouw, p. 89-96.

Weill, A.B., Van der Voo, R., and van der Pluijm, B.A., 2001, Oroclinal bending and evidence against the Pangea megashear: The Cantabria-Asturias arc (northern Spain): Geology, v. 29, no. 11, p. 991-994.

Winchester, J.A., 2002, Micro-continent-promontory interactions: Affinities and possible emplacement mechanism for Proterozoic basement in northern Turkey, in 1st International Symposiumof the Faculty of Mines (ITÜ) on Earth Science and Engineering, Istanbul: Istanbul, ITÜ, p. 76.

Yin, A., and Nie, S., 1996, A Phanerozoic palinspastic reconstruction of China and its neighboring regions, in Yin, A., and Harrison, M., eds., The tectonic evolution of Asia: Cambridge, Cambridge University Press, p. 442-485.

Ziegler, P.A., 1984, Caledonian and Hercynian crustal consolidation of Western and Central Europe-A working hypothesis: Geologie en Mijnbouw 63, p. 93-108.

Ziegler, P.A., 1988, Evolution of the Arctic-North Atlantic and the Western Tethys: American Association of Petroleum Geologists Memoir 43, 198 p.

Ziegler, P.A., and Stampfli, G.M., 2001, Late Paleozoic Early Mesozoic plate boundary reorganisation: Collapse of the Variscan orogen and opening of Neotethys, in Cassinis, R., ed., The continental Permian of the Southern Alps and Sardinia (Italy) regional reports and general correlations: Brescia, Annali Museo Civico Science Naturali, Brescia. v.25, p. 17-34.

Zonenshain, L.P., Kuzmin, M.I., and Kononov, M.V., 1985, Absolute reconstructions of the Paleozoic oceans: Earth and Planetary Science Letters, v. 74 , p. 103-116.

Zonenshain, L.P., Kuzmin, M.I., and Natapov, L.M., 1990, Geology of the USSR: A plate tectonic synthesis: Washington, D.C., American Geophysical Union Geodynamics Series Monograph 21, p. 241.

Zulauf, G., Schitter, F., Riegler, G., Finger, F., Fiala, J., Vejnar, Z., 1999, Age constraints on the Cadomian evolution of the Tepla Barrandian unit (Bohemian Massif) through electron microprobe dating of metamorphic monazite: Zeitschrift der deutschen geologischen Gesellschaft, 150, p. 627-639.

Zwart, H.J. and Dornsiepen, U.F., 1978, The tectonic framework of Central and Western Europe: Geologie en Mijnbouw 57, p. 627-654 